Review

\title{
Hydrogen from Renewables: A Case Study of Glycerol Reforming
}

\author{
Andrea Fasolini ${ }^{1}$, Daniele Cespi ${ }^{2}\left(\mathbb{D}\right.$, Tommaso Tabanelli ${ }^{1, *} \mathbb{C}$, Raffaele Cucciniello ${ }^{3, *} \mathbb{D}$ and \\ Fabrizio Cavani ${ }^{1}$ (D) \\ 1 Dipartimento di Chimica Industriale “Toso Montanari”, Alma Mater Studiorum-Università di Bologna, \\ Viale del Risorgimento 4, 40136 Bologna, Italy \\ 2 NIER Ingegneria SpA, Via C. Bonazzi 2-40013-Castel Maggiore, 40013 Bologna, Italy \\ 3 Department of Chemistry and Biology, "Adolfo Zambelli” Università di Salerno, Via Giovanni Paolo II, 132, \\ 84084 Fisciano, Salerno, Italy \\ * Correspondence: tommaso.tabanelli@unibo.it (T.T.); rcucciniello@unisa.it (R.C.); Tel.: +39-051-2093861 (T.T.); \\ +39-089-969366 (R.C.)
}

Received: 15 July 2019; Accepted: 22 August 2019; Published: 27 August 2019

\begin{abstract}
Biomass is an interesting candidate raw material for the production of renewable hydrogen. The conversion of biomass into hydrogen can be achieved by several processes. In particular, this short review focuses on the recent advances in glycerol reforming to hydrogen, highlighting the development of new and active catalysts, the optimization of reaction conditions, and the use of non-innocent supports as advanced materials for supported catalysts. Different processes for hydrogen production from glycerol, especially aqueous phase reforming (APR) and steam reforming (SR), are described in brief. Thermodynamic analyses, which enable comparison with experimental studies, are also considered. In addition, research advances in terms of life cycle perspective applied to support R\&D activities in the synthesis of renewable $\mathrm{H}_{2}$ from biomass are presented. Lastly, also featured is an evaluation of the studies published, as evidence of the increased interest of both academic research and the industrial community in biomass conversion to energy sources.
\end{abstract}

Keywords: hydrogen; glycerol; Aqueous-phase reforming (APR); steam reforming (SR); Life Cycle Assessment (LCA)

\section{Introduction}

Due to the continuous increase in industrialization, urbanization, and population outgrowth, the demand for energy and its resources is constantly rising. Over the last decades, fossil fuels and their derivatives have remained the most widely exploited energy source for the world, with 97.6 million barrels/day in 2018 and an expected increase up to 112.2 million barrels/day by 2035 [1]. Environmental apprehension over global warming and the search for new sustainable alternatives to fossil energy have recently given rise to a sector of huge impact from the economic, scientific, and industrial standpoints, based on the use of biomass as feedstocks [2-5]. This sector, which bases itself on the 12 Principles of Green Chemistry [6], considers it imperative to develop eco-friendly and energy-efficient processes for the sustainable production of fuels and chemicals [7,8]. Everything suggests that second-to-fourth generation biomass materials could be the major emerging potential sources of organic carbon; moreover, they would be strongly preferable because the fuels resulting from their processing are the only real alternative to fossil fuels. The total amount of energy obtainable from biomass in 2050 will be in the range of 150-450 exajoule/year, corresponding to $76 \times 10^{9}$ barrels of oil energy equivalent [9]. One of the major fuels that could be used because of its abundance via the processing of biomass is surely $\mathrm{H}_{2}$. Hydrogen $\left(\mathrm{H}_{2}\right)$ is a clean energy carrier that can be used in several technologies such as fuel cells to produce electricity [10]. 
Today, great effort has been put into producing hydrogen from renewables because they are considered to be carbon-neutral, since the net amount of $\mathrm{CO}_{2}$ released from their combustion is used by plants during photosynthesis. However, biomass conversion technologies such as gasification and pyrolysis show some limitations and are energy-consuming [11]. Among all waste conversion technologies, the thermochemical conversion process is surely the most known; it includes several subcategories: pyrolysis, hydropyrolysis, reforming, gasification, and liquefaction [12]. While pyrolysis and liquefaction produce bio-oils, gases, and char from biomass by using high temperatures, gasification produces more higher hydrocarbons and syngas from biomass. In this context, an example of extraordinary impact is lignocellulosic (second-generation) biomass, obtainable from agriculture, forestry, industrial, and urban waste residues as a nonedible raw material [13-15]. All these organic residues are useful tools for biofuel production using physiochemical, thermochemical, or biochemical processes, which are fully serviceable for hydrogen production and carbon neutralization. Indeed, lignocellulosic biomasses could be a potential resource for bio- $\mathrm{H}_{2}$ production, because of their low costs, abundance, and worldwide availability [16].

In this review, the conversion of biomass-derived compounds, especially glycerol, to achieve a sustainable $\mathrm{H}_{2}$ production from renewables will be discussed in detail. In particular, the state of the art of the several processes involved in hydrogen production will be analysed with a special focus on the improvements made in the last two decades in the design of both the catalytic systems and the reaction conditions or reactors applied, which have ensured both high conversion of the substrate and an enhanced selectivity in $\mathrm{H}_{2}$.

\section{Glycerol Reforming Processes}

\section{1. $\mathrm{H}_{2}$ from Glycerol: An Overview}

Glycerol (1,2,3-propanetriol) is the main by-product of biodiesel preparation (about $10 \mathrm{wt} \%$ of the final mixture); it is mainly produced by the transesterification of triglycerides using methanol and by the saponification of vegetable oils. In recent years, the growing demand for biodiesel has led to the parallel rapid increase in glycerol production, which is expected to arrive at up to $2.5 \mathrm{Mt} / \mathrm{y}$ in 2020 [17]. This forecast is supported by the greater worldwide availability of glycerol and its consequent price collapse, which has stimulated the interest of industries and research in finding new uses and applications [18-21]. Moreover, in the past few years, the production data of glycerol all over the world confirm this trend. As a matter of fact, in 2013, EU and US biodiesel production facilities produced $1.6 \mathrm{Mt}$ and $1.04 \mathrm{Mt}$ of glycerol respectively. In 2018 the glycerol market was estimated at around $\$ 2.1$ billion. Glycerol will play an important role in the production of chemicals, as demonstrated by Solvay since 2011 with the preparation of bio-based epichlorohydrin $(\mathrm{ECH})$, an epoxide and organochlorine compound useful for epoxy resins, via glycerol chlorination [22]. In the glycerol obtained as a co-product from biodiesel industrial plants (crude glycerol) several impurities (mainly methanol, salts, water, and free fatty acids) are present, thus requiring treatments and purification to render it suitable for pharmaceutical and food applications. On the other hand, crude glycerol can be used directly for $\mathrm{H}_{2}$ production, and this approach can enhance the economic feasibility of biodiesel and promote the use of glycerol [23].

The important role played by the use of glycerol as a starting material for hydrogen production is also confirmed by the publication trend: according to the Scopus ${ }^{\circledR}$ database, there has been a significant increase in the number of publications on this research field over the last 10 years as showed in Figure 1. 


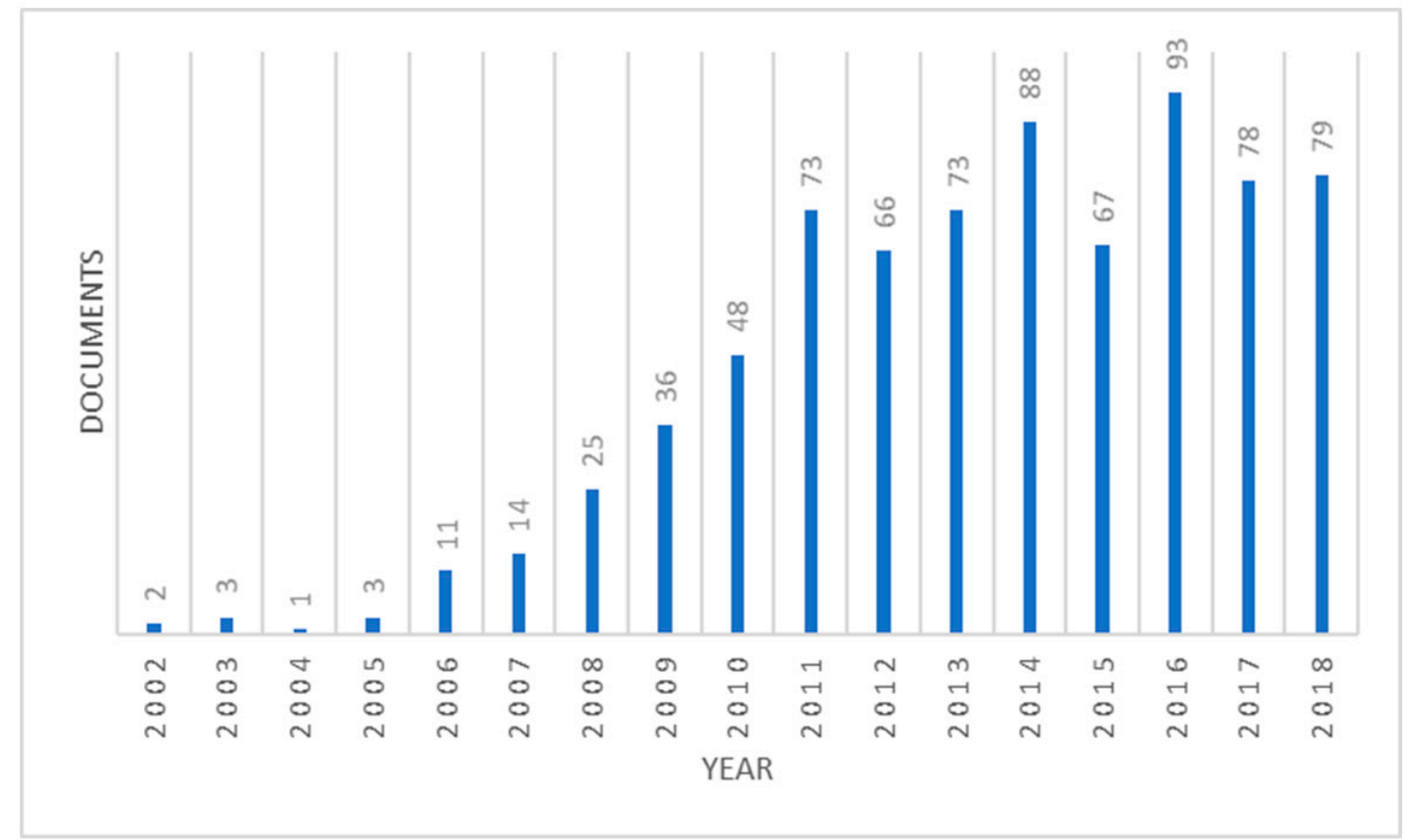

Figure 1. Trend of the peer review manuscripts per year which contain "glycerol reforming" in abstract, keywords, and title. Adapted from Scopus ${ }^{\circledR}[24]$.

From this standpoint, APR and SR are two reasonable valorisation processes. Glycerol reforming is an endothermic reaction and can be summarized as follows [25]:

$$
\mathrm{C}_{3} \mathrm{H}_{8} \mathrm{O}_{3}+\mathrm{xH}_{2} \mathrm{O}+\mathrm{yO}_{2} \rightarrow \mathrm{aH}_{2}+\mathrm{bCO}_{2}+\mathrm{cCO}+\mathrm{dH}_{2} \mathrm{O}+\mathrm{eCH}_{4}
$$

SR occurs at high temperatures (e.g., $800^{\circ} \mathrm{C}$ ) and, generally, low pressure, and is a vapor phase catalytic process where $y=0$ and $x>0$. The main drawbacks of the investigated reaction pathway are catalyst deactivation and high energy consumption.

$$
\mathrm{C}_{3} \mathrm{H}_{8} \mathrm{O}_{3}+3 \mathrm{H}_{2} \mathrm{O} \rightarrow 7 \mathrm{H}_{2}+3 \mathrm{CO}_{2}
$$

Conversely, glycerol APR is performed under mild reaction conditions $\left(220-250{ }^{\circ} \mathrm{C}\right.$ and $\left.2 \mathrm{MPa}\right)$ with a reduced energy consumption, while its limitations include lower $\mathrm{H}_{2}$ selectivity and a higher pressure requirement. In literature, only a few studies focusing on the thermodynamic aspects of glycerol reforming [26] can be found. The overall process comprises several reactions with, according to recently published works, the primary reactions being [27]

$$
\begin{gathered}
\mathrm{C}_{3} \mathrm{H}_{8} \mathrm{O}_{3} \rightarrow 4 \mathrm{H}_{2}+3 \mathrm{CO}(\Delta \mathrm{H}=251 \mathrm{~kJ} / \mathrm{mol}) \text { glycerol decomposition } \\
\mathrm{CO}+\mathrm{H}_{2} \mathrm{O} \rightleftharpoons \mathrm{H}_{2}+\mathrm{CO}_{2}(\Delta \mathrm{H}=-41 \mathrm{~kJ} / \mathrm{mol}) \text { water gas-shift reaction }
\end{gathered}
$$

The sum of Equations (3) and (4) corresponds to Equation (2). As previously described, glycerol reforming is an endothermic process $(\Delta \mathrm{H}=128 \mathrm{~kJ} / \mathrm{mol})$ facilitated by high temperature, low pressure, and high water/glycerol ratio in the feed. Methane formation is facilitated by side reactions at high pressures [27]:

$$
\begin{aligned}
\mathrm{CO}+3 \mathrm{H}_{2} & \rightleftharpoons \mathrm{CH}_{4}+\mathrm{H}_{2} \mathrm{O}(\Delta \mathrm{H}=-206 \mathrm{~kJ} / \mathrm{mol}) \\
\mathrm{CO}_{2}+4 \mathrm{H}_{2} & \rightleftharpoons \mathrm{CH}_{4}+2 \mathrm{H}_{2} \mathrm{O}(\Delta \mathrm{H}=-165 \mathrm{~kJ} / \mathrm{mol}),
\end{aligned}
$$


whereas the increase of both the water:glycerol ratio (increasing glycerol dilution) and temperature makes it possible to decrease methane yield. Coke deposition on the catalyst surface can also affect the reaction [27].

$$
\begin{gathered}
2 \mathrm{CO} \rightleftharpoons \mathrm{CO}_{2}+\mathrm{C}(\Delta \mathrm{H}=-171.5 \mathrm{~kJ} / \mathrm{mol}) \\
\mathrm{CH}_{4} \rightleftharpoons \mathrm{C}+2 \mathrm{H}_{2}(\Delta \mathrm{H}=75 \mathrm{~kJ} / \mathrm{mol}) \\
\mathrm{CO}+\mathrm{H}_{2} \rightleftharpoons \mathrm{H}_{2} \mathrm{O}+\mathrm{C}(\Delta \mathrm{H}=-131 \mathrm{~kJ} / \mathrm{mol}) \\
\mathrm{CO}_{2}+2 \mathrm{H}_{2} \rightleftharpoons 2 \mathrm{H}_{2} \mathrm{O}+\mathrm{C}
\end{gathered}
$$

Based on the above-mentioned reactions, the hydrogen yield is maximized at temperatures higher than $627^{\circ} \mathrm{C}$, at a pressure of $0.1 \mathrm{MPa}$, and in the presence of a water:glycerol molar ratio of 9 . This approach makes it possible to inhibit carbon deposition, while methane formation is drastically reduced [28].

\subsection{Aqueous Phase Reforming of Glycerol}

Aqueous phase reforming (APR) of glycerol Equation (2) is an alternative to gas phase glycerol reforming, especially when glycerol is already produced dissolved in water in the upstream process from biomasses.

The APR process was developed by Dumesic et al. [29-31] and may be applied to different oxygenated substrates $[29,32,33]$. In APR, the liquid solution containing glycerol is heated up in the presence of a catalyst in a one-pot process to produce hydrogen. Lower temperatures than those in glycerol steam reforming are usually used-around $200-250^{\circ} \mathrm{C}$. By working in a closed environment, relatively high autogenic pressures are developed due to the partial water evaporation. However, the reaction takes place in the liquid phase thanks to the low temperature used and the autogenous pressure developed. Thus lower energy is required for reagent vaporization in the APR process, making it a less energy-intensive process than steam reforming. Moreover, unwanted reactions, such as thermal degradation, are minimized thanks to the lower temperatures used. In addition, the presence of aqueous solutions increases the safety of the process and makes it possible to use crude glycerol, thus drastically reducing both the purification steps and the cost of the initial raw material.

Finally, the water-gas shift reaction is facilitated in these conditions of low temperature and high water concentration and occurs after APR, avoiding the need for a separate water-gas shift reactor after the reformer. This leads to the production of a gas stream with low amounts of $\mathrm{CO}$, the presence of which is undesired for certain downstream uses of hydrogen (e.g., fuel cells). In addition, the production of pressurized gas paves the way to the coupling of the APR process with a membrane separation step, a process that is driven by hydrogen partial pressure. However, even $\mathrm{CO}$ hydrogenation is facilitated at low temperature and can consume the hydrogen produced to yield methane (methanation) or higher hydrocarbons. In general, glycerol APR leads to the formation of $\mathrm{H}_{2}$, low amounts of $\mathrm{CO}, \mathrm{CO}_{2}$, methane, and low-chain alkanes $\left(\mathrm{C}_{2}-\mathrm{C}_{3}\right)$ in the gas phase. Conversely, oxygenated compounds such as alcohols, aldehydes, carboxylic acids, and diols are formed in the liquid phase. In particular, the main liquid products are hydroxyacetone, glyceraldehyde, propylene and ethylene glycols, propanaldehyde, acetaldehyde, 2-propanol, 1-propanol, 2-methyl propylene, acetic, propanoic and lactic acids, methanol, and ethanol.

The wide product distribution is due to the complexity of glycerol compared to low-chain hydrocarbons or alcohols and to the numerous reactions involved in the reforming process (Scheme 1). In particular, APR involves dehydration, dehydrogenation, hydrogenation, hydrogenolysis, and C-C cleavage reactions [29]. For these reasons, it is not easy to determine the optimal conditions for APR, as different parameters are involved and can affect one another. In general, gas production is facilitated at high temperature and low pressure [34-37]. The optimum temperature for hydrogen production was found by Özgür et al. [38] to be around $230^{\circ} \mathrm{C}$ in a continuous flow reactor. Reaction rates increase with increasing glycerol concentration [39]. However, glycerol conversion and hydrogen production 
decreased with increasing glycerol concentration in the studies by Manfro et al. and Luo et al. [35,37]. Indeed, hydrogen production was maximized at short reaction times and low glycerol concentrations by Seretic and Tsiacars $[40,41]$. High catalyst amounts facilitated C-C cleavage and the formation of methanol, ethanol, and ethylene glycol [40,41].

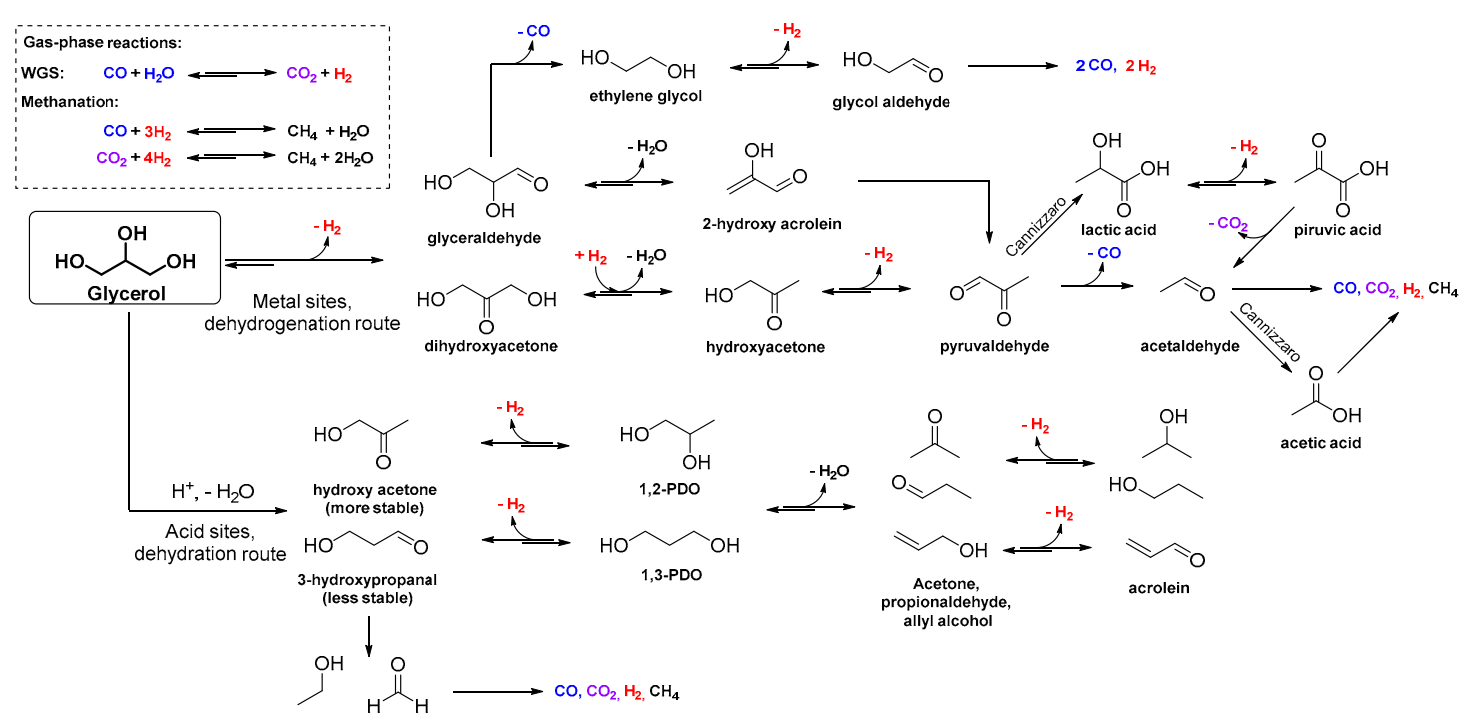

Scheme 1. Possible reaction pathways occurring in glycerol aqueous phase reforming (APR).

\subsubsection{Catalyst for Glycerol Aqueous Phase Reforming}

The role of the catalyst is fundamental in APR reaction. Firstly, glycerol is adsorbed over the active metal sites of the catalyst, then it can follow different routes leading to the formation of different intermediates. In particular, $\mathrm{C}-\mathrm{C}$ cleavage leads to the formation of lower carbon chain molecules (e.g., ethylene glycol). Conversely, $\mathrm{C}-\mathrm{O}$ bond breaking usually uses up hydrogen and leads to alkane formation, whose reforming is thermodynamically hindered at the relatively low temperatures used in APR. For this reason, Dumesic et al. suggested that an APR catalyst should possess $C-C$ cleavage and WGS activity, while being barely active in the $\mathrm{C}-\mathrm{O}$ cleavage, Fischer-Tropsch synthesis, and hydrogenation reactions such as methanation [29,33,42-44]. Thus VIII group metals are usually used in APR reaction, and $\mathrm{Pt}$ is that which most meets the requirements of high activity in $\mathrm{C}-\mathrm{C}$ cleavage and water gas shift (WGS) $[29,43,45]$. Ni is a cheaper alternative to Pt, but it's also active in methanation, which can lead to hydrogen depletion. Nevertheless, catalytic activity can be increased by doping the active metal or using bimetallic catalysts. For example, Sn-modified Ni Raney catalyst provided a good activity in APR of glycerol and other oxygenated compounds [31,46]. The addition of boron also seemed to increase the Ni Raney activity [47]. Moreover, the support properties can highly influence APR reactivity by affecting the dispersion of the active phase, interacting with it, or providing co-catalytic sites. The most-used supports for glycerol APR are shown with their main features in Figure 2. The effect of different supports on the product distribution obtainable in glycerol APR will be discussed extensively in the next paragraphs. 


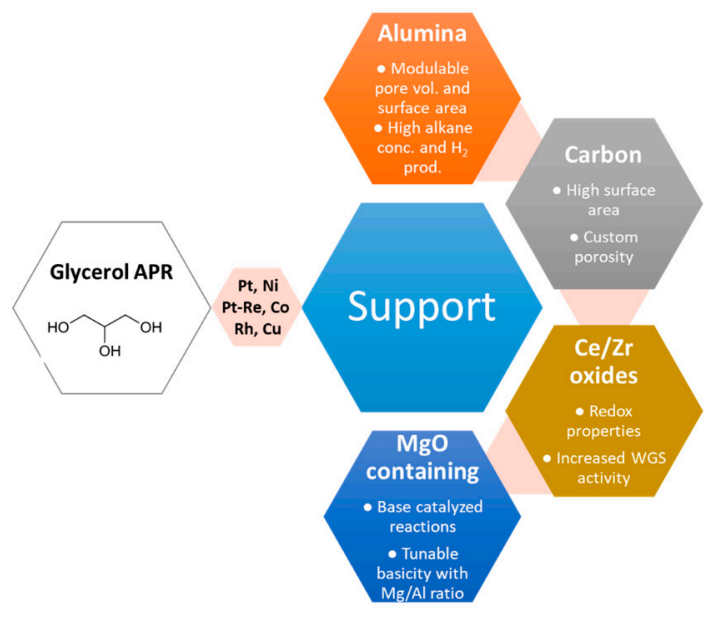

Figure 2. Most used supports in glycerol APR and their main features.

APR Catalysts Supported on Alumina

Among the catalytic supports used in the APR of glycerol, alumina and silica are the materials investigated the most. In particular, a $5 \mathrm{wt} \% \mathrm{Pt}$ supported on $\mathrm{Al}_{2} \mathrm{O}_{3}$ was used to investigate the effect of operational conditions on the reaction in a closed batch reactor [40]. At $200{ }^{\circ} \mathrm{C}$, hydrogen yield was found to decrease with increasing time, thus indicating that methanation and hydrogenation increase considerably at high reaction times, producing alcohol and alkanes. Hydrogen selectivity decreased at high temperatures due to the higher conversion obtained [31], while $\mathrm{CO}_{2}$ and $\mathrm{CH}_{4}$ selectivity rose, indicating that hydrogen is used up to produce methane. However, the conversion to gaseous products increased when time and temperature were raised. Similar results were obtained on Ni supported on silica-alumina. [41] Morales-Marìn et al. studied the effect of reduction temperature $\left(300-850{ }^{\circ} \mathrm{C}\right)$ on a spinel-derived nickel aluminate [48]. The spinel phase made possible the formation of small (around $14 \mathrm{~nm}$ diameter) stable Ni particles which provided glycerol conversion up to $93 \%$, conversion into gaseous product of $57 \%$, and $67 \%$ gas selectivity for the catalyst reduced at the highest temperature $\left(850^{\circ} \mathrm{C}\right)$. The reduction temperature especially affected the liquid product distribution: the dehydrogenation mechanism was facilitated above $700{ }^{\circ} \mathrm{C}$, while dehydration/hydrogenation was more pronounced for the catalysts reduced below $600^{\circ} \mathrm{C}$.

The morphology and surface area of such supports can influence the catalytic activity, metal dispersion, and gas transport from the bulk liquid phase to the metallic active phase. For instance, Doukkali et al. [49] tested $\mathrm{PtNi}, \mathrm{PtCo}, \mathrm{PtFe}, \mathrm{Pt}$, and Ni supported on $\gamma$-alumina by a sol-gel synthetic procedure in acid conditions. This method makes it possible to generate catalysts characterized by a high surface area, micro/meso porosity, and high metal dispersion, which proved to be more active than in the analogous catalysts prepared by impregnation. Pt presence facilitated the reduction of the other metallic active phase thanks to hydrogen spillover during reduction. The catalysts containing Fe and Co were outperformed by the others due to the higher methanation and lower $\mathrm{C}-\mathrm{C}$ cleavage properties of the former. PtNi resulted more active than the single metal Pt and Ni catalysts, albeit due to a higher metal loading. However, a synergy between $\mathrm{Pt}$ and Ni was observed. This catalyst was particularly active in the formation of gaseous products, namely hydrogen, methane, and ethylene; while methanol, acetaldehyde, ethylene glycol, and other alcohols were found in the liquid phase.

Another study evidenced the effect of the average pore diameter of the support: different $\mathrm{Pt}$ precursors were deposited on $\gamma$-alumina, Puralox ${ }^{\circledR}$ (mixture of $\gamma, \delta$, and $\theta$ alumina phases), and Catapal $B^{\circledR}$ (bohemite modification) supports to provide a catalyst with Pt metal loading of $3 \mathrm{wt} \%$, and tested in a continuous flow reactor [50]. The reaction rate increased together with the average pore diameter of the support, with the Puralox ${ }^{\circledR}$-based catalyst providing a glycerol conversion of $57 \%$ and a turnover frequency of $89\left(\mathrm{~mol} \mathrm{H}_{2}\right) /\left(\right.$ moles of surface metal $\left.{ }^{*} \mathrm{~min}\right)$ associated with an average pore diameter of $33.6 \mathrm{~nm}$. An intermediate activity ( $26 \%$ of glycerol conversion) was obtained by 
Catapal $\mathrm{B}^{\circledR}$, which was characterized by a smaller pore diameter $(7.4 \mathrm{~nm})$; while the lowest conversion $(8 \%)$ was obtained with $\gamma$-alumina, which has an average pore diameter of $3.4 \mathrm{~nm}$. Therefore, it was suggested that the occurrence of substrate transport limitations through the catalyst porosity must be avoided in order to increase both conversion and selectivity. Interestingly, the Puralox ${ }^{\circledR}$-supported catalyst was tested with a crude glycerol mixture but provided low conversion and faster deactivation, in this case due to the poisoning of the active sites of the catalyst by the impurities of the crude mixture (e.g., $\mathrm{NaCl})$.

Alumina-containing samples, however, may undergo a phase transition to bohemite in APR conditions when reaction time increases. In fact, Cifcti et al. [51] investigated the catalytic activity of $\mathrm{Pt}$ deposited on $\gamma$-alumina, silica, and amorphous silica-alumina with different $\mathrm{Al}$ content. Al-containing samples underwent bohemite formation, which provided an increased surface acidity that resulted in enhanced glycerol dehydration into hydroxyacetone and hydrogenation to obtain 1,2-propanediol. Finally, the interaction between the support and the active phase can affect the selectivity of the process, as hydrogen spillover from $\mathrm{Pt}$ to alumina can lead to a higher alkane concentration [45].

\section{APR Catalysts Supported on Carbon}

Carbon-based supports are a valid alternative to inorganic oxides for developing an active APR catalyst. Their main advantage is the large surface area they can provide, together with custom porosity, thermal conductivity, and stability. Carbon supports have various forms, but the most used ones in glycerol APR are respectively active carbons, nanotubes, carbon black, and mesoporous carbon. For example, Wen et al. used Pt over an active carbon catalyst with a large surface area $\left(721.3 \mathrm{~m}^{2} / \mathrm{g}\right)$, which proved to be stable under reaction conditions and provided a hydrogen rich gas phase with a conversion to gaseous products of $17.2 \%$ [45].

Carbon-based supports can be useful when comparing the activity of different active phases due to the low intrinsic activity of these supports. For example, Kunkes et al. studied the effect of Re addition to Pt over carbon black, evidencing that the presence of Re increased the production of $\mathrm{H}_{2}$, $\mathrm{CO}, \mathrm{CO}_{2}$, and light alkanes [52]. Moreover, Re promoted the WGS reaction, decreasing the $\mathrm{CO}: \mathrm{CO}_{2}$ ratio and increasing the $\mathrm{H}_{2}: \mathrm{CO}$ one. The faster $\mathrm{CO}$ removal by enhanced WGS is correlated with the increased activity [53,54]. This is due to the formation of Pt-Re nanoparticles in which Re lowers the $\mathrm{Pt}-\mathrm{CO}$ binding energy and slows down sintering, as also confirmed by TEM and X-ray absorption spectroscopy [55]. The interaction between $\mathrm{Pt}$ and Re was further studied on active carbon showing that the catalyst undergoes oxidation under hydrothermal condition, suggesting that the active phase is actually a partially oxidized Pt-Re species, in which Re provides both metal and acid sites [56,57]. The latter facilitates dehydration reactions, increasing selectivity toward alkanes and liquid products at the expense of hydrogen selectivity. $\mathrm{H}_{2}$ production, however, can be increased by the addition of $\mathrm{KOH}$ which reduces the occurrence of acid-catalysed pathways [58]. Re promotion was also evidenced on carbon-supported Rh catalysts [59]. Interestingly, the catalytic activity of Rh-Re catalysts outperformed an analogous Pt-Re, even though only Pt is more active than Rh in APR; nevertheless, the higher cost of the Rh-Re catalyst could be a decisive drawback for its application at a higher scale. Lastly, Mo doping on Pt on carbon black also increases the turnover rate and selectivity because Mo also reduces the $\mathrm{Pt}-\mathrm{CO}$ binding energy [60]. However, an accurate comparison between the promoting effect of both Mo and $R e$ is not feasible due to the different reaction conditions employed in the reported investigations.

Three dimensionally mesoporous carbons were also used in the APR of glycerol after impregnation with Pt [61]. The unique mesoporous structure of these catalysts provided a synergic effect at high reaction temperatures and pressures, giving increased carbon conversion to gas and hydrogen production. Also, nano-sized and micro-sized mesoporous carbons were screened and the dimension of particles proved to influence the catalytic activity; in fact, nano-sized catalysts provided better APR activity thanks to their more efficient mass transfer and diffusion of products and reactants.

Carbon nanotubes are another good option for supported APR catalysts. For example, $\mathrm{Cu}$ and Ni or mixtures of them were deposited on multiwalled carbon nanotubes (MWCN) with a surface area of 
$296 \mathrm{~m}^{2} / \mathrm{g}$, to study the effect and synergy of these two active phases on glycerol APR [62]. Cu addition resulted in the suppression of methanation and enhanced WGS reaction. The best results, namely $84 \%$ glycerol conversion and $86 \%$ hydrogen selectivity, were obtained with a MWCN with $1 \%$ of $\mathrm{Cu}$ and $12 \%$ of $\mathrm{Ni}$. These high values were assigned to the large surface area of the support and the high support-metal interaction. Carbon nanotubes with added $\mathrm{CaO}$ were also used in a sorption-enhanced glycerol APR. In such a process, $\mathrm{CO}_{2}$ was removed from the reaction environment to form $\mathrm{CaCO}_{3}$. $\mathrm{CO}_{2}$ removal enhanced hydrogen selectivity by decreasing methanation [63].

\section{APR Catalysts Supported on Ce and Zr Oxides}

$\mathrm{CeO}_{2}$ and $\mathrm{Ce}-\mathrm{Zr}$ oxides have been widely used in the heterogeneous catalysis as promoters or bare supports thanks to their excellent thermal and mechanical resistance and redox properties of $\mathrm{Ce}$, which is able to easily switch between $\mathrm{Ce}^{3+}$ and $\mathrm{Ce}^{4+}$ oxidation states [64-66]. This peculiar behaviour is enhanced by the deposition of metals over Ce-based supports and when $\mathrm{Zr}$ is added to $\mathrm{Ce}$, forming a mixed oxide solution. These properties can boost the catalytic activity toward both WGS reaction and/or the oxidation of carbonaceous deposits over the active phase, resulting in a limitation of the catalyst deactivation [67-70]. Ce and Zr oxides can be used as supports or as doping agents, usually added together with the metallic active phases over alumina supports. In this way, an enhanced catalytic activity can be obtained thanks to the interaction between the Ce or $\mathrm{Zr}$ oxide and the active phase. Iriondo et al. found that the addition of $\mathrm{Ce}$ and $\mathrm{Zr}$ to Ni- $\mathrm{Al}_{2} \mathrm{O}_{3}$-based catalysts enhances the initial glycerol conversion and hydrogen selectivity thanks to the decoration effect of $\mathrm{Ce}$ over $\mathrm{Ni}$ or the strong interaction between $\mathrm{Ni}$ and $\mathrm{Zr}$ [71]. $\alpha-\mathrm{Al}_{2} \mathrm{O}_{3}$ modified with $\mathrm{Ce}$ and $\mathrm{Zr}$ (atomic ratio: $\mathrm{Ce}_{4} \mathrm{Zr}_{1}$ ) led to the formation of smaller Pt particles and contributed to WGS activity increasing glycerol conversion [72]. This was also observed on non-noble metal active phases such as Ni-Co. [73] Ce-doped $\mathrm{Pt}_{-} \mathrm{Al}_{2} \mathrm{O}_{3}$ makes it possible to increase glycerol conversion up to $95 \%$, with a parallel carbon conversion to gas of $85 \%$ and hydrogen yield $(80 \%)$, thanks to an improved metal dispersion made

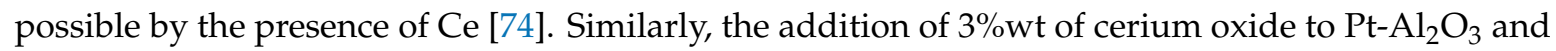
$\mathrm{PtNi}-\mathrm{Al}_{2} \mathrm{O}_{3}$ catalysts enhanced their activity and selectivity [75]. Interestingly, the catalysts were tested for $30 \mathrm{~h}$ and showed good stability.

Ce- or Zr-containing supports can be synthesized by different techniques that affect active phase dispersion and metal support interaction. Manfro et al. obtained high glycerol conversion for a $\mathrm{Ni}$-based catalyst deposited on $\mathrm{CeO}_{2}$ synthesized by combustion ( $30 \%$ ) compared to wet impregnation or co-precipitation synthesis due to the formation of smaller Ni crystallites [35]. Re addition on $\mathrm{Pt}$ was also studied on a Ce/Zr-based support: it confirmed the enhancing effect of Re, together with an increased WGS activity given by the support [76].

Lastly, a parameter affecting the performances of $\mathrm{Ce} / \mathrm{Zr}$ oxide is the Ce: $\mathrm{Zr}$ ratio. An activity order of $\mathrm{Ce}_{0.3} \mathrm{Zr}_{0.7} \mathrm{O}_{2}>\mathrm{Ce}_{0.5} \mathrm{Zr}_{0.5} \mathrm{O}_{2}>\mathrm{Ce}_{0.7} \mathrm{Zr}_{0.3} \mathrm{O}_{2}>\mathrm{ZrO}_{2}>\mathrm{CeO}_{2}$ was reported for Ni-supported catalysts [77]. Conversely, an optimal Ce:Zr ratio of 1 was found for Pt-supported catalysts, giving hydrogen yields of up to $93 \%$ [78]. In this case, the order of reactivity was as follows: $\mathrm{Pt}_{0.05} \mathrm{Ce}_{0.475} \mathrm{Zr}_{0.475} \mathrm{O}_{2}>$ $\mathrm{Pt}_{0.05} \mathrm{Ce}_{0.29} \mathrm{Zr}_{0.66} \mathrm{O}_{2}>\mathrm{Pt}_{0.05} \mathrm{Zr}_{0.95} \mathrm{O}_{2}>\mathrm{Pt}_{0.05} \mathrm{Ce}_{0.66} \mathrm{Zr}_{0.29} \mathrm{O}_{2}>\mathrm{Pt}_{0.05} \mathrm{Ce}_{0.95} \mathrm{O}_{2}$.

\section{APR Catalysts Supported on $\mathrm{Mg}$ and $\mathrm{Mg} / \mathrm{Al}$ Oxides}

$\mathrm{MgO}$ addition to Al-based supports or as a bare support is used to provide basic sites to the catalytic systems. The electro-donating behaviour of a basic support such as $\mathrm{MgO}$ enhances hydrogen formation while limiting hydrocarbon production [79]. These aspects can influence the catalytic activity in the APR reaction [45]. The basicity effect was studied by Guo et al. by comparing the activity of $\mathrm{Pt}$ over $\mathrm{MgO}, \mathrm{Al}_{2} \mathrm{O}_{3}, \mathrm{CeO}_{2}, \mathrm{TiO}_{2}$, and $\mathrm{SiO}_{2}$ [80]. The order of activity was $\mathrm{Pt} / \mathrm{MgO}>\mathrm{Pt} / \mathrm{Al}_{2} \mathrm{O}_{3}>\mathrm{Pt} / \mathrm{CeO}_{2}$ $>\mathrm{Pt} / \mathrm{TiO}_{2}>\mathrm{Pt} / \mathrm{SiO}_{2}$ and was correlated with WGS activity which is facilitated by basic sites. Similarly, also when $\mathrm{Cu}$ was used as an active phase, $\mathrm{MgO}$ still outperformed alumina and silica, thanks to the support basicity which stabilized copper nanoparticles [81]. The basic feature of $\mathrm{MgO}$ can be modulated by the introduction of other metals, especially $\mathrm{Al}$, inside the periclase structure. An easy 
method for obtaining supports with a defined $\mathrm{Mg}$ : $\mathrm{Al}$ ratio is the ex-hydrotalcite route. In fact, $\mathrm{Mg} / \mathrm{Al}$ mixed oxides were obtained by the calcination of a suitable precursor (hydrotalcites) at a relatively high temperature $\left(400-500^{\circ} \mathrm{C}\right)$. Also in this case, however, the catalytic results showed that hydrogen production is increased by increasing the $\mathrm{Mg}$ : $\mathrm{Al}$ ratio [82]. Nevertheless, this parameter was found to be significant in the case of $\mathrm{MgO}-\mathrm{Al}_{2} \mathrm{O}_{3}$ supports prepared by coprecipitation and loaded with $\mathrm{Ni}$. Both $\mathrm{Ni} / \mathrm{MgO}$ and $\mathrm{Ni} / \mathrm{Al}_{2} \mathrm{O}_{3}$ were outperformed by the mixed supports, with $\mathrm{Ni} / \mathrm{Al}_{2} \mathrm{Mg}_{1}$ providing the best results at $92 \%$ glycerol conversion and $76 \%$ hydrogen selectivity [83].

Finally, titanium oxide has been used as a catalytic support for the APR process $[80,84]$. In particular, $\mathrm{Pt} / \mathrm{TiO}_{2}$ was able to achieve a $27 \%$ carbon conversion to gas and a hydrogen yield of $14.8 \%[80]$.

In general, glycerol APR has been studied in different conditions and has been proven to be able to provide good to excellent hydrogen yields at high glycerol conversions. Table 1 summarizes some of the most promising results reported in literature in terms of glycerol conversion, hydrogen yield, and carbon conversion to gas.

Table 1. APR results in terms of glycerol conversion, hydrogen yield, and carbon conversion to gas shown for different supported metal-based catalysts.

\begin{tabular}{|c|c|c|c|c|c|c|c|}
\hline Catalyst & $\mathrm{T}\left({ }^{\circ} \mathrm{C}\right)$ & Time (h) & Process & Conversion & H2 Yield & Conv. to Gas & Ref \\
\hline $\mathrm{Pt} 5 \% / \mathrm{Al}_{2} \mathrm{O}_{3}$ & 240 & 4 & Batch & 84 & 41 & 14.1 & [40] \\
\hline $\mathrm{Ni} 65 \% / \mathrm{SiO}_{2}-\mathrm{Al}_{2} \mathrm{O}_{3}$ & 240 & 4 & Batch & 76 & n.a. & $48^{* * *}$ & [41] \\
\hline $\mathrm{Ni} / \mathrm{Al}_{2} \mathrm{O}_{3}$ & 250 & / & Fixed bed & 93 & n.a. & 53 & [48] \\
\hline PtNiAl & 230 & / & Fixed bed & 97 & n.a. & 58 & [49] \\
\hline $\mathrm{Pt} 3 \% / \mathrm{Al}_{2} \mathrm{O}_{3}$ & 250 & l & Fixed bed & 45 & $83 *$ & n.a. & [50] \\
\hline $\mathrm{Pt3} \% \operatorname{Re} 3 \% / \mathrm{C}$ & 225 & 1 & Fixed bed & 68.2 & n.a. & n.a. & {$[56]$} \\
\hline Pt3\%Re3\%/C & 225 & l & Fixed bed & 88.7 & $24.5 *$ & $58.5^{* * *}$ & [59] \\
\hline Pt5\%Mo (1:1)/C & 230 & / & Fixed bed & 26 & n.a. & n.a. & [60] \\
\hline Pt7\%/CMK-9 & 260 & l & Fixed bed & n.a. & 98.7 & 94.7 & [61] \\
\hline 1Cu-12Ni/MWNT & 240 & l & Fixed bed & 84 & $86^{*}$ & n.a. & [62] \\
\hline Pt5\%Ni (1.5:1)/CNT & 230 & 4 & Batch & 81.2 & n.a. & 15.3 & [63] \\
\hline $\mathrm{Pt} / \mathrm{AC}$ & 230 & 1 & Fixed Bed & n.a. & $69.6^{* *}$ & 17.2 & [45] \\
\hline $\mathrm{Ni} / \mathrm{CeO}_{2}-\mathrm{Al}_{2} \mathrm{O}_{3}$ & 225 & / & Fixed bed & 36 & $32 * *$ & n.a. & [71] \\
\hline $\mathrm{Pt} 1 \% / \mathrm{Al}_{2} \mathrm{O}_{3}-\mathrm{CeO}_{2}-\mathrm{ZrO}_{2}$ & 250 & 2 & Batch & 29 & $81 *$ & n.a. & [72] \\
\hline $\mathrm{Ni1Co} 3-2 \mathrm{Ce} / \mathrm{Al}_{2} \mathrm{O}_{3}$ & 220 & / & Fixed bed & 55 & 55 & n.a. & [73] \\
\hline $\mathrm{Pt} 3 \% \mathrm{Ce} 3 \% / \mathrm{Al}_{2} \mathrm{O}_{3}$ & 240 & / & Fixed bed & 95 & 80 & 85 & [74] \\
\hline $\mathrm{Pt} 1 \% \mathrm{Ni} 6 \% \mathrm{Ce} 3 \% / \mathrm{Al}_{2} \mathrm{O}_{3}$ & 240 & l & Fixed bed & 96 & 96 & 94 & [75] \\
\hline $\mathrm{Ni10} \% / \mathrm{Ce}_{0.3} \mathrm{Zr}_{0.7} \mathrm{O}_{2}$ & 250 & I & Fixed bed & 90 & $45^{*}$ & 99 & [77] \\
\hline $\mathrm{PtRh} / \mathrm{MgO}$ & 250 & / & Fixed bed & 62 & $97 *$ & 52 & [79] \\
\hline $\mathrm{Pt} / \mathrm{MgO}$ & 225 & / & Fixed bed & n.a. & 28 & 48 & [80] \\
\hline $\mathrm{Cu} / \mathrm{MgO}$ & 200 & 6 & Batch & 55 & n.a. & n.a. & [81] \\
\hline $\mathrm{Pt} / \mathrm{Mg}(\mathrm{Al}) \mathrm{O}$ & 225 & 30 & Batch & n.a. & $64 *$ & n.a. & [82] \\
\hline $\mathrm{Pt} / \mathrm{TiO}_{2}$ & 225 & l & Fixed Bed & $\begin{array}{l}\text { n.a. } \\
\text { n.a. }\end{array}$ & $\begin{array}{c}\text { n.a. } \\
27\end{array}$ & $\begin{array}{l}\text { n.a. } \\
14.8\end{array}$ & [80] \\
\hline
\end{tabular}

${ }^{*}$ Hydrogen selectivity; ${ }^{* *} \%$ in the gas products; ${ }^{* * *}$ Selectivity to gas products, n.a. not available.

Furthermore, the product distribution can be tuned by using different conditions and catalysts, obtaining in some way a hydrogen-enriched gaseous mixture (low $\mathrm{CO}, \mathrm{CO}_{2}$, and other light compound content). However, only a few of the studies mentioned in this work used crude glycerol as the starting feed $[34,50,85,86]$. In a perspective of industrial applications and integration with biorefineries, greater effort in this direction is essential in order to strongly limit the cost of the raw material and make the overall process economically feasible. Moreover, some studies have focused on catalyst stability, which is a very important parameter for the application of these materials. Evaluating catalyst stability under real conditions is another fundamental step toward the implementation of glycerol APR. Finally, the use of cheap active phases and supports, which can be easily produced in large quantities, would enhance the spreading of this process. 


\subsection{Glycerol Steam Reforming (SR)}

Glycerol SR is the most investigated industrial process for producing hydrogen from this polyol. It takes place at high temperatures (in the range of $400-700{ }^{\circ} \mathrm{C}$ ) and atmospheric pressure over a suitable catalyst. In most cases, an acqueous glycerol solution is continuously fed into an evaporator and then introduced into a continuous-flow fixed-bed reactor by an inert flow (usually nitrogen or helium). During SR, the hydrogen thus obtained is released from the reaction mixture with a consequently increased reaction yield. Furthermore, the use of SR technology would not require significant adjustments in the current industrial process for $\mathrm{H}_{2}$ production [87]. The main advantages of SR over other reforming processes include operations at moderate pressures and production of higher $\mathrm{H}_{2}$ concentrations with high substrate conversion. The overall reaction is represented by Equation N.2., whereas the potential benefit of obtaining large amounts of $\mathrm{H}_{2}$ on the basis of a hydrogen:glycerol molar ratio of 7 is very evident. According to several studies, the best results for SR are obtained in the temperature range of $525-575{ }^{\circ} \mathrm{C}$; conversely, a decreased selectivity toward $\mathrm{H}_{2}$ is observed at lower temperatures with the formation of methane and carbon dioxide [88]. Generally speaking, SR proceeds at $1 \mathrm{~atm}$, but vacuum pressures (which would permit lower temperatures) might be preferred, in order to reduce the sintering of the catalyst and energy costs. The yield and selectivity of the reaction toward the production of hydrogen is strongly affected by water/glycerol feed rate, while at ratios above 9 the $\mathrm{H}_{2}$ yields are maximized [89]. On the other hand, the water amount must be limited to reduce the volume of the evaporator, to limit vaporization costs, and to increase productivity. In recent years, several interesting works have been published about the preparation, characterization, use, and deactivation of solid catalysts for glycerol SR [28]. In particular, several authors have reported on the possible use of metal-based supported material as suitable catalysts for the target reaction. In particular, $\mathrm{Ni}, \mathrm{Pt}, \mathrm{Co}$, and $\mathrm{Ru}$ are active metal catalysts, whereas the nature of the support strongly affects the stability and activities of the materials due to the different metal-support interactions [90-92]. As already stated, however, glycerol SR is a high-energy-intensive process and new strategies to overcome this limitation have been recently investigated. As a matter of fact, as reported by many researchers $[93,94]$, a possible solution is to feed a small amount of oxygen to promote the partial oxidation of glycerol (Equation (11)), following combined oxidative reforming strategies:

$$
\mathrm{C}_{3} \mathrm{H}_{8} \mathrm{O}_{3}+7 / 2 \mathrm{O}_{2} \rightarrow 3 \mathrm{CO}_{2}+4 \mathrm{H}_{2} \mathrm{O}(\Delta \mathrm{H}=-1565 \mathrm{~kJ} / \mathrm{mol})
$$

Oxy-reforming undergoes with the simultaneous occurrence of pyrolysis (Equation (3)), WGS (Equation (4)) and combustion (Equation (11)):

$$
\mathrm{C}_{3} \mathrm{H}_{8} \mathrm{O}_{3}+3 / 2 \mathrm{H}_{2} \mathrm{O}+3 / 4 \mathrm{O}_{2} \rightarrow 11 / 2 \mathrm{H}_{2}+3 \mathrm{CO}_{2}(\Delta \mathrm{H}=-240 \mathrm{~kJ} / \mathrm{mol})
$$

Moreover, operating conditions can be optimized in order to perform this reaction without the need for external energy inputs. This way, oxy-reforming can produce $5.5 \mathrm{~mol}$ of hydrogen from $1 \mathrm{~mol}$ of glycerol, while producing the necessary heat for the process. In this scenario, several catalysts have been used and some interesting results are reported by Dauenhauer and co-workers [95] in the presence of $\mathrm{Rh}-\mathrm{Ce} / \mathrm{Al}_{2} \mathrm{O}_{3}$ catalysts (hydrogen selectivity is $79 \%$ ) and by Wang [96] using Ni-based catalysts characterized by high activity, stability, and resistance to carbon deposition. Chang and co-workers [97] reported on glycerol autothermal steam reforming over $\mathrm{Ni} / \mathrm{CeO}_{2} / \mathrm{Al}_{2} \mathrm{O}_{3}$ catalyst in a packed bed reactor. Results show that the glycerol conversion of $99.56 \%$ was achieved at a temperature of $973 \mathrm{~K}$. The most significant and promising results in glycerol SR are discussed in the following sections, with a special emphasis on the effect of the different supports used. Below, the most used supports for glycerol SR are shown in Figure 3. 


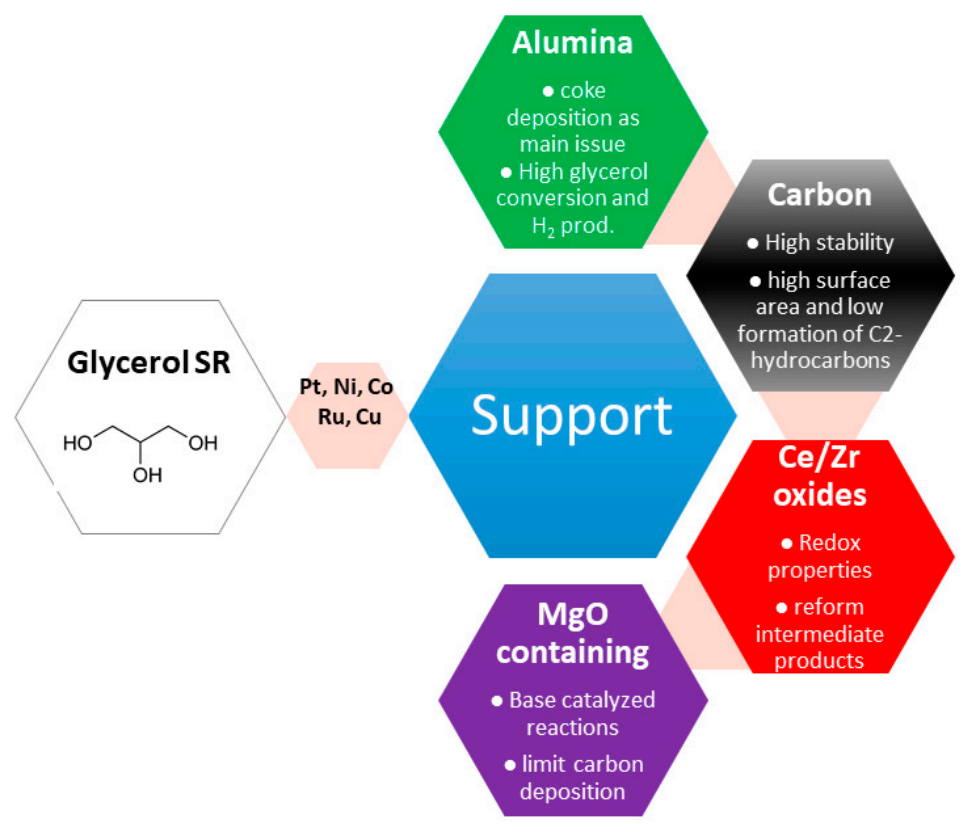

Figure 3. The most used supports in glycerol steam reforming (SR) and their main features.

\subsubsection{Catalyst for Glycerol Steam Reforming}

\section{SR Catalysts Supported on Alumina}

Ni-based catalysts have been extensively investigated for glycerol SR. Different research groups have analysed the catalytic performance of $\mathrm{Ni} / \mathrm{Al}_{2} \mathrm{O}_{3}$. Iriondo et al. reported the total conversion of glycerol using $12.6 \mathrm{wt} \% \mathrm{Ni} / \gamma-\mathrm{Al}_{2} \mathrm{O}_{3}$ with a good selectivity to hydrogen (yield $=50 \%, 500{ }^{\circ} \mathrm{C}$, $4 \mathrm{~atm}, \mathrm{WHSV}=7.7 \mathrm{~h}^{-1}$ and $10 \mathrm{wt} \%$ glycerol, $8 \mathrm{~h}$ ) [98]. The deactivation of alumina-based catalysts seems to be strongly influenced by carbonaceous deposition after $8 \mathrm{~h}$ time on stream at 600 and $650{ }^{\circ} \mathrm{C}$ as highlighted by Sanchez et coworkers [98-100]. These experimental results have been further and clearly described by many studies in which the formation of coke deposits is related to dehydration, cracking, and polymerization reactions on the acid sites of $\mathrm{Al}_{2} \mathrm{O}_{3}$ [101]. Pant et al. [102] also reported that $\mathrm{Ni} / \mathrm{Al}_{2} \mathrm{O}_{3}$ catalysts showed higher catalyst sintering than $\mathrm{Ni}$-ceria. The Authors demonstrated that the sintering of the $\mathrm{Ni}$ active phase is related to a transition of $\mathrm{Ni}$ aluminate crystalline phase [100-105]. In this context, the use of a promoter is claimed to improve catalytic performances by delaying deactivation phenomena. Interesting results are reported by Iriondo et al. in the presence of $8.4 \mathrm{wt} \% \mathrm{Ni} / \gamma-\mathrm{Al}_{2} \mathrm{O}_{3} / 6 \mathrm{wt} \% \mathrm{La}_{2} \mathrm{O}_{3}$ with a quantitative glycerol conversion after $8 \mathrm{~h}$ of reaction at $500{ }^{\circ} \mathrm{C}, 4 \mathrm{~atm}$ and a WHSV (weight hourly space velocity) of $7.7 \mathrm{~h}^{-1}$ [99]. The use of alumina as the support was also reported for Co active phase by Cheng et coworkers [106], whereas the presence of basic and acid sites on the catalyst surface affect the catalytic performance and, as evidenced for $\mathrm{Ni} / \mathrm{Al}_{2} \mathrm{O}_{3}$ catalyst, the deactivation mechanism is related to carbon deposition which can be removed in the presence of oxygen.

\section{SR Catalysts Supported on Carbon}

The use of metal-based catalysts supported on carbon has been explored, and outstanding results are reported by Dumesic and coworkers $[107,108]$. In these works, $\mathrm{Pt} / \mathrm{C}$ shows higher stability than other Pt-based catalysts characterized by the use of different supports $\left(\mathrm{MgO} / \mathrm{ZrO}_{2}, \mathrm{ZrO}_{2}, \mathrm{CeO}_{2} / \mathrm{ZrO}_{2}\right.$, and $\mathrm{Al}_{2} \mathrm{O}_{3}$ ). These results are related to the very low formation of C2-hydrocarbons. Very recently, Liu [109] reported the use of Ni on carbon nanotubes (CNTs) prepared by impregnation. Results show that both the surface area and the dispersion of active metallic Ni nanoparticle co-affected catalytic 
performances, achieving a high gaseous products yield (86.4\%) with high hydrogen selectivity $(72.9 \%)$ when the reaction was conducted at a temperature as low as $375^{\circ} \mathrm{C}$.

\section{SR Catalysts Supported on Ce and Zr Oxides}

The prominent role of $\mathrm{CeO}_{2}$ as the support for glycerol SR has been recently discussed [110,111]. In this context, the interaction between the active phase and ceria strongly influenced hydrogen yield [111]. Wang reported the preparation of $\mathrm{Ni} / \mathrm{CeO}_{2}$ using the glow discharge plasma technique for glycerol SR. Results show that glow discharge plasma treatment enhances nickel dispersion and $\mathrm{Ni}-\mathrm{Ce}$ interaction with the formation of a Ni-O-Ce composite. The catalyst thus obtained shows enhanced $\mathrm{H}_{2}$ selectivity $(44.7 \%)$ and reaction stability, in comparison to the calcined counterparts.

$\mathrm{ZrO}_{2}$ has also been efficiently used as a promoter despite the fact that it is not active by itself [112]. As a matter of fact, the addition of $\mathrm{ZrO}_{2}$ to $\mathrm{Ni} / \mathrm{Al}_{2} \mathrm{O}_{3}$ enhanced the $\mathrm{H}_{2}$ yield and the ability of the catalyst to reform intermediate products at $500{ }^{\circ} \mathrm{C}$. This process is enhanced by the $\mathrm{ZrO}_{2}$ capacity to activate water through the formation of $\mathrm{ZrO}_{2}-\mathrm{Al}_{2} \mathrm{O}_{3}$ species, which facilitates the reduction of $\mathrm{Ni}^{2+}$ to the metallic state [113].

\section{SR Catalysts Supported on Mg Oxides}

The use of $\mathrm{MgO}$ as a support is described only in a few works [114]. Adhikari et al. [115] reported on a glycerol conversion of $100 \%$ and a hydrogen yield of $57 \%$ over $\mathrm{Ni} / \mathrm{MgO}$ catalysts at high temperature $\left(650^{\circ} \mathrm{C}\right)$. $\mathrm{Ru} / \mathrm{MgO}$ shows very low glycerol conversion to gaseous products compared to other samples. This behaviour is probably ascribable to the lower reducibility of the dispersed ruthenium species to metallic ruthenium, with a drastic drop in the number of active sites [116]. Nevertheless, the use of $\mathrm{MgO}$ is reported to limit carbon deposition by facilitating its gasification, so its role as a promoter deserves further investigations $[117,118]$. Some relevant results in the presence of supported catalysts are shown in Table 2.

Table 2. Glycerol steam reforming, conversion, and $\mathrm{H}_{2}$ yield using the most promising metal-supported catalysts.

\begin{tabular}{cccccc}
\hline Catalyst & T $\left({ }^{\circ} \mathbf{C}\right)$ & Time $(\mathbf{h})$ & Conversion & $\mathbf{H}_{\mathbf{2}}$ Yield & Ref \\
\hline $\mathrm{Ni} 12.6 \% / \gamma-\mathrm{Al}_{2} \mathrm{O}_{3}$ & 500 & 8 & 100 & 50 & {$[98]$} \\
$\mathrm{Ni} 8.4 \% / \mathrm{La} 2 \mathrm{O}_{3} 6 \%-\gamma-\mathrm{Al}_{2} \mathrm{O}_{3}$ & 500 & 8 & 100 & 99.7 & {$[99]$} \\
$\mathrm{Ni} 15 \% / \mathrm{CNT}$ & 450 & - & 80.7 & 83.6 & {$[109]$} \\
$\mathrm{Pt} 5 \% / \mathrm{C}$ & 400 & 3 & 60 & 37 & {$[108]$} \\
$\mathrm{Ni} 9.6 \% / \mathrm{MgO}$ & 650 & - & 100 & 57 & {$[115]$} \\
\hline
\end{tabular}

\section{Life Cycle Assessment (LCA) Approach for A Sustainable Hydrogen Production from Glycerol}

Life cycle perspective aims to evaluate environmentally friendly solutions by considering all the flows (energy, materials, wastes, by-products, etc.) involved in the stages which represent the entire process or part of it. LCA (Life Cycle Assessment) is a standardized $[119,120]$ and well-known method for assessing several sectors of bioeconomy, such as bio-based chemicals [121], bioenergy [122], and bio-waste [123]. In general, LCA is helpful as a support in decision-making during R\&D stages, since it may drive choices in the selection of materials for catalysis. On the other hand, a life cycle approach can be used to compare two or more processes in terms of different feedstocks and reaction conditions, to select the better alternative from an environmental standpoint. Literature collects some examples of LCA applied to $\mathrm{H}_{2}$ production through the reforming of renewables sources. They are briefly described below. Susmozas et al. [124] studied the environmental and energy performances of biohydrogen produced in the EU via the steam reforming of glycerol (GSR) and bio-oil (BSR), counterposing their results with those achieved by conventional $\mathrm{H}_{2}$ from the steam reforming of methane. In this study, LCA was combined with process simulation: Aspen Plus ${ }^{\circledR}$ software was selected to design and simulate the processing plants; this helped researchers during data collection for LCA inventory. In this simulation, glycerol is obtained (i) as by-product from rapeseed biodiesel and (ii) 
from bio-oil produced through the fast pyrolysis of poplar biomass. The assessment was carried out by considering several environmental impact indexes, including the global warming potential (GWP) - to address implications on climate change-and the cumulative energy demand (CED) to estimate total energy requirements and the non-renewable fraction. Results proved to be strongly affected by the choice of feedstock. Bio-oil fast pyrolysis of poplar biomass seems to be a better feedstock for steam reforming, reducing CED $(-30 \%)$ from non-renewables and GWP $(-70 \%)$ compared to glycerol from biodiesel production. The use of renewable resources, however, does not necessarily guarantee better performances: traditional steam reforming still seems competitive thanks to the gaseous nature of methane feedstock.

Nevertheless, in the past few years great effort has been made to evaluate both the techno-economic and environmental performances of glycerol reforming for hydrogen and power production. In particular, Hilmioglu et al. [125] modelled and simulated different glycerol SR processes, by changing both the reactor design and the reaction conditions, in order to optimize key plant performance indicators. On the other hand, Cormos et al. [126] compared the conventional glycerol SR (with heat provided by an external burner fed with hydrogen purification tail gas) with the oxygen autothermal reforming approach. In both cases the effect of the addition of a $\mathrm{CO}_{2}$-dedicated sequestration setup (using methyl diethanolamine as the chemical absorbent) was also taken into consideration. Interestingly, the technical, economic, and environmental analyses underlined that conventional SR has a slightly higher energy and cost efficiency than autothermal reforming with or without carbon capture apparatus (which leads to a cost penalty, expressed as production costs, of around $25 \%$ for hydrogen and $33 \%$ for power, compared to cases without carbon capture).

Another extremely innovative and interesting approach is the supercritical water reforming of glycerol (SCWR). In this case, glycerol is continuously fed with water at high temperature and pressure (e.g., $450{ }^{\circ} \mathrm{C}, 240 \mathrm{~atm}$ ) obtaining interesting hydrogen yields and selectivity, also by feeding crude glycerol ( $80 \mathrm{wt} \%$ glycerol, $20 \mathrm{wt} \%$ of water and methanol) to the reactor [127].

This approach was techno-economically assessed considering future states of technology, because there is no demo plant using this technology (using both Aspen Plus (V11, Aspen Technology, Bedford, MA, USA) and CAPCOST software) [128,129]. Again, glycerol SCWR was compared with autothermal supercritical water reforming (ASCWR) by co-feeding oxygen to the reformer. Interestingly, working in supercritical conditions, ASCWR performs better than SCWR in terms of energy efficiency (thermal self-sufficient conditions). Nevertheless, the capital investment and operational difficulties of ASCWR process leads to relatively high hydrogen production costs (5.75 $\$ / \mathrm{kg})$. This value is still too high compared to conventional technologies (e.g., methane SR); in a future scenario, however, some possible improvements in supercritical water (SCW) reforming performance may lead to a decrease in the estimated renewable hydrogen price $[130,131]$.

As mentioned above, LCA is easily adaptable during R\&D activities. Its powerfulness is totally expressed when combined with process design (Aspen Plus ${ }^{\circledR}$ ) and DoE (design of experiment). Khila et al. [132] adopted this strategy to investigate the best reaction condition for the production of $\mathrm{H}_{2}$ from raw bioethanol ATR (autothermal reforming). The use of a non-purified bio-alcohol ensures the minimization of heat consumption during distillation procedures. In such a case, LCA analysis was used first to estimate all the stages which contribute most to the entire impact per selected category, and then to compare alternative routes to $\mathrm{H}_{2}$ in order to identify the greener one. In this case, the electricity generation and ethanol production from sugar beet molasses seem to affect all environmental impact categories the most. Nevertheless, the comparison with a conventional $\mathrm{H}_{2}$ production system (SMR) shows that ATR emits about half of the SMR life cycle Greenhouse gases (GHGs). DoE was then applied to examine the simultaneous influence of the reformer temperature and the $\mathrm{S}: \mathrm{C}$ ratio on the process energetic, exergetic, and environmental performances. Experiments found $\mathrm{S}: \mathrm{C}=4$ and $\mathrm{T}=800{ }^{\circ} \mathrm{C}$ to be the best and most accurate parameters for the entire bioethanol-to-hydrogen process. This enabled researchers to identify the recommended configuration with best performances and productivity. 
Therefore, these examples confirm how the integration of iterative and holistic approaches may help designers, working in the field of $\mathrm{H}_{2}$ production from bio-sources, identify the best combination of technological solutions to help companies and research centres save money and pursue better alternatives for a future low-carbon society.

\section{Conclusions}

Over the past few years, significant progress has been made in the development of active heterogeneous catalytic systems capable of promoting hydrogen production through glycerol reforming processes. In particular, two main approaches have been discussed in detail: glycerol steam reforming (SR), and glycerol aqueous phase reforming (APR). A preliminary thermodynamic study has been described in order to better contextualize the reactions involved in these processes. In both cases, the uses of the most active metal catalysts (mainly $\mathrm{Ni}$ and $\mathrm{Pt}$ ) have been discussed, with a special focus on the investigation of the effects of different promoters and supports on hydrogen selectivity and catalyst stability. Indeed, in many cases, catalyst deactivation processes, due to coking, leaching, or sintering effects, constitute one of the main problems of these approaches. Nevertheless, the optimization of reaction conditions and reactor design makes it possible to achieve very good results in both batch and continuous flow conditions. In particular, in the latter cases, catalyst stability needs to be further investigated under real conditions and longer reaction times, in order to better understand the scalability of the process.

In spite of the fact that a direct comparison between the catalytic systems is not easy because of different operative conditions and synthesis routes employed, some outstanding results in terms of glycerol conversion and hydrogen yields have been reported. Just to mention a few, Ni supported over lanthanum oxide-modified alumina permitted achieving a 100\% conversion and $99.7 \%$ hydrogen yield in glycerol SR [41]. In the aqueous phase, good results were obtained by Pt-Ni-Ce impregnated on alumina in a continuous flow (96\% conversion and $96 \%$ hydrogen yield) [72], while Pt over alumina gave an $84 \%$ glycerol conversion and a $41 \%$ hydrogen yield in batch conditions [40].

Nevertheless, the great majority of the works presented in literature have focused only on the upgrading of purified glycerol. It is worthy of note that the possibility to use crude glycerol as a raw material, derived directly from the bio-diesel manufacturing plant, would boost the applications of these technologies at the industrial scale. Indeed, crude glycerol is a cheaper raw material, actually making the overall process economically feasible and competitive with the technologies existing today.

Finally, the LCA approach was discussed in order to suggest the adoption of green metrics capable of improving the sustainability of these processes and enhancing a short-term development at the industrial scale.

Author Contributions: Conceptualization, A.F., D.C., T.T. and R.C.; data curation, A.F., D.C., T.T. and R.C.; writing - original draft preparation, A.F.; writing — review and editing, T.T. and R.C.; supervision, F.C.

Funding: This research received no external funding.

Conflicts of Interest: The authors declare no conflict of interest.

\section{References}

1. Mohanty, P.; Pant, K.K.; Mittal, R. Hydrogen Generation from Biomass Materials: Challenges and Opportunities. Adv. Bioenergy 2015, 4, 93-108.

2. Tabanelli, T.; Giliberti, C.; Mazzoni, R.; Cucciniello, R.; Cavani, F. An innovative synthesis pathway to benzodioxanes: The peculiar reactivity of glycerol carbonate and catechol. Green Chem. 2019, 21, 329-338. [CrossRef]

3. Swarr, T.E.; Cucciniello, R.; Cespi, D. Environmental certifications and programs roadmap for a sustainable chemical industry. Green Chem. 2019, 21, 375-380. [CrossRef] 
4. Erythropel, H.; Zimmerman, J.; Winter, T.M.; de Petitjean, L.; Melnikov, F.; Lam, C.; Lounsbury, A.; Mellor, K.; Janković, N.; Tu, Q.; et al. The Green ChemisTREE: 20 years after taking root with the 12 principles. Green Chem. 2018, 20, 1929-1961. [CrossRef]

5. Ricciardi, M.; Falivene, L.; Tabanelli, T.; Proto, A.; Cucciniello, R.; Cavani, F. Bio-Glycidol Conversion to Solketal over Acid Heterogeneous Catalysts: Synthesis and Theoretical Approach. Catalysts 2018, 8, 391. [CrossRef]

6. Anastas, P.T.; Warner, J.C. Green Chemistry: Theory and Practice; Oxford University Press: Oxford, UK, 1998.

7. Cucciniello, R.; Pironti, C.; Capacchione, C.; Proto, A.; Di Serio, M. Efficient and selective conversion of glycidol to 1,2-propanediol over Pd/C catalyst. Catal. Commun. 2016, 77, 98-102. [CrossRef]

8. Cucciniello, R.; Ricciardi, M.; Vitiello, R.; Di Serio, M.; Proto, A.; Capacchione, C. Synthesis of Monoalkyl Glyceryl Ethers by Ring Opening of Glycidol with Alcohols in the Presence of Lewis Acids. ChemSusChem 2016, 9, 3272-3275. [CrossRef]

9. Marion, P.; Bernela, B.; Piccirilli, A.; Estrine, B.; Patouillard, N.; Guilbot, J.; Jérôme, F. Sustainable chemistry: How to produce better and more from less? Green Chem. 2017, 19, 4973-4989. [CrossRef]

10. Italiano, C.; Bizkarra, K.; Barrio, V.; Cambra, J.; Pino, L.; Vita, A. Renewable hydrogen production via steam reforming of simulated bio-oil over Ni-based catalysts. Int. J. Hydrog. Energy 2019, 44, 14671-14682. [CrossRef]

11. Vaidya, P.D.; Lopez-Sanchez, J.A.; Lopez-Sanchez, J.A. Review of Hydrogen Production by Catalytic Aqueous-Phase Reforming. ChemistrySelect 2017, 2, 6563-6576. [CrossRef]

12. Callison, J.; Subramanian, N.; Rogers, S.; Chutia, A.; Gianolio, D.; Catlow, C.; Wells, P.; Dimitratos, N. Directed aqueous-phase reforming of glycerol through tailored platinum nanoparticles. Appl. Catal. B Environ. 2018, 238, 618-628. [CrossRef]

13. Collard, F.-X.; Blin, J. A review on pyrolysis of biomass constituents: Mechanisms and composition of the products obtained from the conversion of cellulose, hemicelluloses and lignin. Renew. Sustain. Energy Rev. 2014, 38, 594-608. [CrossRef]

14. Liu, Y.; Nie, Y.; Lu, X.; Zhang, X.; He, H.; Pan, F.; Zhou, L.; Liu, X.; Ji, X.; Zhang, S. Cascade utilization of lignocellulosic biomass to high-value products. Green Chem. 2019, 21, 3499-3535. [CrossRef]

15. Vozniuk, O.; Tabanelli, T.; Tanchoux, N.; Millet, J.-M.M.; Albonetti, S.; Di Renzo, F.; Cavani, F.; Millet, J.-M. Mixed-Oxide Catalysts with Spinel Structure for the Valorization of Biomass: The Chemical-Loop Reforming of Bioethanol. Catalysts 2018, 8, 332. [CrossRef]

16. Nakagawa, Y.; Tamura, M.; Tomishige, K. Recent development of production technology of diesel- and jet-fuel-range hydrocarbons from inedible biomass. Fuel Process. Technol. 2019, 193, 404-422. [CrossRef]

17. Cespi, D.; Mastragostino, G.; LaRocca, S.; Iaconi, A.; Chieregato, A.; Dubois, J.-L.; Cavani, F.; Passarini, F.; Vassura, I. Glycerol as feedstock in the synthesis of chemicals: A life cycle analysis for acrolein production. Green Chem. 2015, 17, 343-355. [CrossRef]

18. Ricciardi, M.; Cespi, D.; Celentano, M.; Genga, A.; Malitesta, C.; Proto, A.; Capacchione, C.; Cucciniello, R. Bio-propylene glycol as value-added product from Epicerol ${ }^{\circledR}$ process. Sustain. Chem. Pharm. 2017, 6, 10-13. [CrossRef]

19. Ricciardi, M.; Passarini, F.; Capacchione, C.; Proto, A.; Barrault, J.; Cucciniello, R.; Cespi, D. First Attempt of Glycidol-to-Monoalkyl Glyceryl Ethers Conversion by Acid Heterogeneous Catalysis: Synthesis and Simplified Sustainability Assessment. ChemSusChem 2018, 11, 1829-1837. [CrossRef]

20. Pagliaro, M.; Rossi, M. The Future of Glycerol, 2nd ed.; RSC Publishing: Cambridge, UK, 2010.

21. Zhou, C.-H.; Beltramini, J.N.; Fan, Y.-X.; Lu, G.Q. Chemoselective catalytic conversion of glycerol as a biorenewable source to valuable commodity chemicals. Chem. Soc. Rev. 2008, 37, 527-549. [CrossRef]

22. Cespi, D.; Cucciniello, R.; Ricciardi, M.; Vassura, I.; Capacchione, C.; Passarini, F.; Proto, A. A simplified early stage assessment of process intensification: Glycidol as a value-added product from epichlorohydrin industry wastes. Green Chem. 2016, 18, 4559-4570. [CrossRef]

23. Ardi, M.; Aroua, M.K.; Hashim, N.A. Progress, prospect and challenges in glycerol purification process: A review. Renew. Sustain. Energy Rev. 2015, 42, 1164-1173. [CrossRef]

24. Scopus-Analyze Search Results. Available online: https://www.scopus.com/term/analyzer.uri?sid= 89b0464d85a8b46183adbccf4d567335\&origin=resultslist\&src=s\&s=TITLE-ABS-KEY\%28glycerol+ reforming\%29\&sort=plf-f\&sdt=b\&sot=b\&sl=33\&count=804\&analyzeResults=Analyze+results\&t $x$ Gid $=$ 3b3718dae53f4b123bd516710613e8e1 (accessed on 4 July 2019). 
25. Delparish, A.; Koc, S.; Çağlayan, B.S.; Avci, A.K. Oxidative steam reforming of glycerol to synthesis gas in a microchannel reactor. Catal. Today 2019, 323, 200-208. [CrossRef]

26. Ashraf, J.; Kumar, A. Thermodynamic evaluation of hydrazine assisted glycerol reforming for syngas production and coke inhibition. Int. J. Hydrog. Energy 2018, 43, 12999-13008. [CrossRef]

27. Auber, M. EFFET Catalytique de Certains Inorganiques sur la Sélectivité des Réactions de Pyrolyse Rapide de Biomasses et de Leurs Constituants. Ph.D. Thesis, Institut National Polytechnique de Lorraine, Nancy, France, 2009.

28. Vaidya, P.D.; Rodrigues, A.E.; Rodrigues, A. Glycerol Reforming for Hydrogen Production: A Review. Chem. Eng. Technol. 2009, 32, 1463-1469. [CrossRef]

29. Davda, R.; Shabaker, J.; Huber, G.; Cortright, R.; Dumesic, J. A review of catalytic issues and process conditions for renewable hydrogen and alkanes by aqueous-phase reforming of oxygenated hydrocarbons over supported metal catalysts. Appl. Catal. B Environ. 2005, 56, 171-186. [CrossRef]

30. Dusastre, V.; Cortright, R.D.; Davda, R.R.; Dumesic, J.A. Hydrogen from catalytic reforming of biomass-derived hydrocarbons in liquid water. In Materials for Sustainable Energy; World Scientific Pub Co Pte Ltd.: Singapore, 2010; pp. 289-292.

31. Huber, G.W.; Shabaker, J.W.; Dumesic, J.A. Raney Ni-Sn Catalyst for $\mathrm{H}_{2}$ Production from Biomass-Derived Hydrocarbons. Chemin 2003, 34, 2075-2077. [CrossRef]

32. Cruz, I.O.; Ribeiro, N.F.; Aranda, D.A.; Souza, M.M. Hydrogen production by aqueous-phase reforming of ethanol over nickel catalysts prepared from hydrotalcite precursors. Catal. Commun. 2008, 9, 2606-2611. [CrossRef]

33. Shabaker, J. Aqueous-phase reforming of methanol and ethylene glycol over alumina-supported platinum catalysts. J. Catal. 2003, 215, 344-352. [CrossRef]

34. Remon, J.; Giménez, J.; Valiente, A.; Garcia, L.; Arauzo, J. Production of gaseous and liquid chemicals by aqueous phase reforming of crude glycerol: Influence of operating conditions on the process. Energy Convers. Manag. 2016, 110, 90-112. [CrossRef]

35. Manfro, R.L.; Da Costa, A.F.; Ribeiro, N.F.; Souza, M.M. Hydrogen production by aqueous-phase reforming of glycerol over nickel catalysts supported on $\mathrm{CeO}_{2}$. Fuel Process. Technol. 2011, 92, 330-335. [CrossRef]

36. Roy, D.; Subramaniam, B.; Chaudhari, R.V. Aqueous phase hydrogenolysis of glycerol to 1,2-propanediol without external hydrogen addition. Catal. Today 2010, 156, 31-37. [CrossRef]

37. Luo, N.; Fu, X.; Cao, F.; Xiao, T.; Edwards, P.P. Glycerol aqueous phase reforming for hydrogen generation over Pt catalyst Effect of catalyst composition and reaction conditions. Fuel 2008, 87, 3483-3489. [CrossRef]

38. Özgür, D.Ö.; Uysal, B.Z. Hydrogen production by aqueous phase catalytic reforming of glycerine. Biomass Bioenergy 2011, 35, 822-826.

39. Wawrzetz, A.; Peng, B.; Hrabar, A.; Jentys, A.; Lemonidou, A.; Lercher, J.; Lemonidou, A. Towards understanding the bifunctional hydrodeoxygenation and aqueous phase reforming of glycerol. J. Catal. 2010, 269, 411-420. [CrossRef]

40. Seretis, A.; Tsiakaras, P. Aqueous phase reforming (APR) of glycerol over platinum supported on $\mathrm{Al}_{2} \mathrm{O}_{3}$ catalyst. Renew. Energy 2016, 85, 1116-1126. [CrossRef]

41. Seretis, A.; Tsiakaras, P. Hydrogenolysis of glycerol to propylene glycol by in situ produced hydrogen from aqueous phase reforming of glycerol over $\mathrm{SiO}_{2}-\mathrm{Al}_{2} \mathrm{O}_{3}$ supported nickel catalyst. Fuel Process. Technol. 2016, 142, 135-146. [CrossRef]

42. Davda, R.; Shabaker, J.; Huber, G.; Cortright, R.; Dumesic, J. Aqueous-phase reforming of ethylene glycol on silica-supported metal catalysts. Appl. Catal. B Environ. 2003, 43, 13-26. [CrossRef]

43. Huber, G.W.; Dumesic, J.A. An overview of aqueous-phase catalytic processes for production of hydrogen and alkanes in a biorefinery. Catal. Today 2006, 111, 119-132. [CrossRef]

44. Aqueous-phase reforming of ethylene glycol over supported Pt and Pd bimetallic catalysts. Appl. Catal. B Environ. 2006, 62, 226-235. [CrossRef]

45. Wen, G.; Xu, Y.; Ma, H.; Xu, Z.; Tian, Z. Production of hydrogen by aqueous-phase reforming of glycerol. Int. J. Hydrog. Energy 2008, 33, 6657-6666. [CrossRef]

46. Shabaker, J.; Huber, G.; Dumesic, J. Aqueous-phase reforming of oxygenated hydrocarbons over Sn-modified Ni catalysts. J. Catal. 2004, 222, 180-191. [CrossRef] 
47. Guo, Y.; Liu, X.; Azmat, M.U.; Xu, W.; Ren, J.; Wang, Y.; Lu, G. Hydrogen production by aqueous-phase reforming of glycerol over Ni-B catalysts. Int. J. Hydrog. Energy 2012, 37, 227-234. [CrossRef]

48. Morales-Marín, A.; Ayastuy, J.; Iriarte-Velasco, U.; Gutiérrez-Ortiz, M. Nickel aluminate spinel-derived catalysts for the aqueous phase reforming of glycerol: Effect of reduction temperature. Appl. Catal. B Environ. 2019, 244, 931-945. [CrossRef]

49. El Doukkali, M.; Iriondo, A.; Cambra, J.F.; Jalowiecki-Duhamel, L.; Mamede, A.; Dumeignil, F.; Arias, P.L. Pt monometallic and bimetallic catalysts prepared by acid sol-gel method for liquid phase reforming of bioglycerol. J. Mol. Catal. A Chem. 2013, 368, 125-136. [CrossRef]

50. Lehnert, K.; Claus, P. Influence of Pt particle size and support type on the aqueous-phase reforming of glycerol. Catal. Commun. 2008, 9, 2543-2546. [CrossRef]

51. Ciftci, A.; Peng, B.; Jentys, A.; Lercher, J.A.; Hensen, E.J. Support effects in the aqueous phase reforming of glycerol over supported platinum catalysts. Appl. Catal. A Gen. 2012, 431, 113-119. [CrossRef]

52. Kunkes, E.L.; Simonetti, D.A.; Dumesic, J.A.; Pyrz, W.D.; Murillo, L.E.; Chen, J.G.; Buttrey, D.J. The role of rhenium in the conversion of glycerol to synthesis gas over carbon supported platinum-rhenium catalysts. J. Catal. 2008, 260, 164-177. [CrossRef]

53. Ciftci, A.; Ligthart, D.M.; Sen, A.O.; Van Hoof, A.J.; Friedrich, H.; Hensen, E.J. Pt-Re synergy in aqueous-phase reforming of glycerol and the water-gas shift reaction. J. Catal. 2014, 311, 88-101. [CrossRef]

54. Ciftci, A.; Ligthart, D.M.; Hensen, E.J. Influence of Pt particle size and Re addition by catalytic reduction on aqueous phase reforming of glycerol for carbon-supported $\mathrm{Pt}(\mathrm{Re})$ catalysts. Appl. Catal. B Environ. 2015, 174, 126-135. [CrossRef]

55. Daniel, O.M.; DeLaRiva, A.; Kunkes, E.L.; Datye, A.K.; Dumesic, J.A.; Davis, R.J. X-ray Absorption Spectroscopy of Bimetallic Pt-Re Catalysts for Hydrogenolysis of Glycerol to Propanediols. ChemCatChem 2010, 2, 1107-1114. [CrossRef]

56. Zhang, L.; Karim, A.M.; Engelhard, M.H.; Wei, Z.; King, D.L.; Wang, Y. Correlation of Pt-Re surface properties with reaction pathways for the aqueous-phase reforming of glycerol. J. Catal. 2012, 287, 37-43. [CrossRef]

57. Wei, Z.; Karim, A.; Li, Y.; Wang, Y. Elucidation of the Roles of Re in Aqueous-Phase Reforming of Glycerol over Pt-Re/C Catalysts. ACS Catal. 2015, 5, 7312-7320. [CrossRef]

58. King, D.L.; Zhang, L.; Xia, G.; Karim, A.M.; Heldebrant, D.J.; Wang, X.; Peterson, T.; Wang, Y. Aqueous phase reforming of glycerol for hydrogen production over Pt-Re supported on carbon. Appl. Catal. B Environ. 2010, 99, 206-213. [CrossRef]

59. Ciftci, A.; Ligthart, D.A.J.M.; Hensen, E.J.M. Aqueous phase reforming of glycerol over Re-promoted Pt and Rh catalysts. Green Chem. 2014, 16, 853-863. [CrossRef]

60. Dietrich, P.J.; Wu, T.; Sumer, A.; Dumesic, J.A.; Jellinek, J.; Delgass, W.N.; Ribeiro, F.H.; Miller, J.T. Aqueous Phase Glycerol Reforming with Pt and PtMo Bimetallic Nanoparticle Catalysts: The Role of the Mo Promoter. Top. Catal. 2013, 56, 1814-1828. [CrossRef]

61. Kim, T.-W.; Kim, M.-C.; Yang, Y.-C.; Kim, J.-R.; Jeong, S.-Y.; Kim, C.-U. Hydrogen production via the aqueous phase reforming of polyols over CMK-9 mesoporous carbon supported platinum catalysts. Int. J. Hydrog. Energy 2015, 40, 15236-15243. [CrossRef]

62. Rahman, M. H2 production from aqueous-phase reforming of glycerol over $\mathrm{Cu}-\mathrm{Ni}$ bimetallic catalysts supported on carbon nanotubes. Int. J. Hydrog. Energy 2015, 40, 14833-14844. [CrossRef]

63. He, C.; Zheng, J.; Wang, K.; Lin, H.; Wang, J.-Y.; Yang, Y. Sorption enhanced aqueous phase reforming of glycerol for hydrogen production over Pt-Ni supported on multi-walled carbon nanotubes. Appl. Catal. B Environ. 2015, 162, 401-411. [CrossRef]

64. Trovarelli, A. Catalytic Properties of Ceria and $\mathrm{CeO}_{2}$-Containing Materials. Catal. Rev. 1996, 38, 439-520. [CrossRef]

65. Fornasiero, P.; Dimonte, R.; Rao, G.; Kaspar, J.; Meriani, S.; Trovarelli, A.; Graziani, M. Rh-Loaded CeO $2-\mathrm{ZrO}_{2}$ Solid-Solutions as Highly Efficient Oxygen Exchangers: Dependence of the Reduction Behavior and the Oxygen Storage Capacity on the Structural-Properties. J. Catal. 1995, 151, 168-177. [CrossRef]

66. Trovarelli, A.; De Leitenburg, C.; Boaro, M.; Dolcetti, G. The utilization of ceria in industrial catalysis. Catal. Today 1999, 50, 353-367. [CrossRef] 
67. Noronha, F.B.; Fendley, E.C.; Soares, R.R.; Alvarez, W.E.; Resasco, D.E. Correlation between catalytic activity and support reducibility in the $\mathrm{CO}_{2}$ reforming of methane over Pt/CexZr1-xO2 catalysts. Chem. Eng. J. 2001, 82, 21-31. [CrossRef]

68. Basile, F.; Mafessanti, R.; Fasolini, A.; Fornasari, G.; Lombardi, E.; Vaccari, A. Effect of synthetic method on CeZr support and catalytic activity of related Rh catalyst in the oxidative reforming reaction. J. Eur. Ceram. Soc. 2019, 39, 41-52. [CrossRef]

69. Roh, H.-S.; Jun, K.-W.; Dong, W.-S.; Park, S.-E.; Baek, Y.-S. Highly stable Ni catalyst supported on Ce-ZrO $\mathrm{Zr}_{2}$ for oxy-steam reforming of methane. Catal. Lett. 2001, 74, 31-36. [CrossRef]

70. Wang, S.; $\mathrm{Lu}, \mathrm{G}$. (Max) Role of $\mathrm{CeO}_{2}$ in $\mathrm{Ni} / \mathrm{CeO}_{2}-\mathrm{Al}_{2} \mathrm{O}_{3}$ catalysts for carbon dioxide reforming of methane. Appl. Catal. B Environ. 1998, 19, 267-277. [CrossRef]

71. Iriondo, A.; Barrio, V.L.; Cambra, J.F.; Arias, P.L.; Guemez, M.B.; Navarro, R.M.; Sánchez-Sánchez, M.C.; Fierro, J.L.G.; Yerga, R.N. Hydrogen Production from Glycerol Over Nickel Catalysts Supported on $\mathrm{Al}_{2} \mathrm{O}_{3}$ Modified by Mg, Zr, Ce or La. Top. Catal. 2008, 49, 46-58. [CrossRef]

72. Barbelli, M.L.; Pompeo, F.; Santori, G.F.; Nichio, N.N. Pt catalyst supported on $\alpha-\mathrm{Al}_{2} \mathrm{O}_{3}$ modified with $\mathrm{CeO}_{2}$ and $\mathrm{ZrO}_{2}$ for aqueous-phase-reforming of glycerol. Catal. Today 2013, 213, 58-64. [CrossRef]

73. Luo, N.; Ouyang, K.; Cao, F.; Xiao, T. Hydrogen generation from liquid reforming of glycerin over Ni-Co bimetallic catalyst. Biomass Bioenergy 2010, 34, 489-495. [CrossRef]

74. Rahman, M.M.; Church, T.L.; Minett, A.I.; Harris, A.T. Effect of $\mathrm{CeO}_{2}$ Addition to $\mathrm{Al}_{2} \mathrm{O}_{3}$ Supports for Pt Catalysts on the Aqueous-Phase Reforming of Glycerol. ChemSusChem 2013, 6, 1006-1013. [CrossRef]

75. Rahman, M.M.; Church, T.L.; Variava, M.F.; Harris, A.T.; Minett, A.I. Bimetallic Pt-Ni composites on ceria-doped alumina supports as catalysts in the aqueous-phase reforming of glycerol. RSC Adv. 2014, 4, 18951-18960. [CrossRef]

76. Ciftci, A.; Eren, S.; Ligthart, D.A.J.M.; Hensen, E.J.M. Platinum-Rhenium Synergy on Reducible Oxide Supports in Aqueous-Phase Glycerol Reforming. ChemCatChem 2014, 6, 1260-1269. [CrossRef]

77. Bastan, F.; Kazemeini, M.; Larimi, A.S. Aqueous-phase reforming of glycerol for production of alkanes over Ni/CexZr1-xO2 nano-catalyst: Effects of the support's composition. Renew. Energy 2017, 108, 417-424. [CrossRef]

78. Larimi, A.S.; Kazemeini, M.; Khorasheh, F. Aqueous phase reforming of glycerol using highly active and stable Pt0.05CexZr0.95-xO2 ternary solid solution catalysts. Appl. Catal. A Gen. 2016, 523, 230-240. [CrossRef]

79. Larimi, A.S.; Kazemeini, M.; Khorasheh, F. Highly selective doped PtMgO nano-sheets for renewable hydrogen production from APR of glycerol. Int. J. Hydrog. Energy 2016, 41, 17390-17398. [CrossRef]

80. Guo, Y.; Azmat, M.U.; Liu, X.; Wang, Y.; Lu, G. Effect of support's basic properties on hydrogen production in aqueous-phase reforming of glycerol and correlation between WGS and APR. Appl. Energy 2012, 92, $218-223$. [CrossRef]

81. Zhou, C.H.; Deng, K.; Di Serio, M.; Xiao, S.; Tong, D.S.; Li, L.; Lin, C.X.; Beltramini, J.; Zhang, H.; Yu, W.H. Cleaner hydrothermal hydrogenolysis of glycerol to 1,2-propanediol over $\mathrm{Cu}$ /oxide catalysts without addition of external hydrogen. Mol. Catal. 2017, 432, 274-284. [CrossRef]

82. Boga, D.A.; Oord, R.; Beale, A.M.; Chung, Y.-M.; Bruijnincx, P.C.A.; Weckhuysen, B.M. Highly Selective Bimetallic Pt-Cu/Mg(Al)O Catalysts for the Aqueous-Phase Reforming of Glycerol. ChemCatChem 2013, 5, 529-537. [CrossRef]

83. Bastan, F.; Kazemeini, M.; Larimi, A.; Maleki, H. Production of renewable hydrogen through aqueous-phase reforming of glycerol over Ni/Al2O3MgO nano-catalyst. Int. J. Hydrog. Energy 2018, 43, 614-621. [CrossRef]

84. Delgado, S.N.; Yap, D.; Vivier, L.; Especel, C. Influence of the nature of the support on the catalytic properties of Pt-based catalysts for hydrogenolysis of glycerol. J. Mol. Catal. A Chem. 2013, 367, 89-98. [CrossRef]

85. Seretis, A.; Tsiakaras, P. Crude bio-glycerol aqueous phase reforming and hydrogenolysis over commercial $\mathrm{SiO}_{2} \mathrm{Al}_{2} \mathrm{O}_{3}$ nickel catalyst. Renew. Energy 2016, 97, 373-379. [CrossRef]

86. Boga, D.A.; Liu, F.; Bruijnincx, P.C.A.; Weckhuysen, B.M. Aqueous-phase reforming of crude glycerol: Effect of impurities on hydrogen production. Catal. Sci. Technol. 2016, 6, 134-143. [CrossRef]

87. Schwengber, C.A.; Alves, H.J.; Schaffner, R.A.; Da Silva, F.A.; Sequinel, R.; Bach, V.R.; Ferracin, R.J. Overview of glycerol reforming for hydrogen production. Renew. Sustain. Energy Rev. 2016, 58, 259-266. [CrossRef]

88. Charisiou, N.; Polychronopoulou, K.; Asif, A.; Goula, M. The potential of glycerol and phenol towards H2 production using steam reforming reaction: A review. Surf. Coat. Technol. 2018, 352, 92-111. [CrossRef] 
89. Rodrigues, A.; Bordado, J.C.; Santos, R.G. dos Upgrading the Glycerol from Biodiesel Production as a Source of Energy Carriers and Chemicals-A Technological Review for Three Chemical Pathways. Energies 2017, 10, 1817. [CrossRef]

90. Wang, B.; Xiong, Y.; Han, Y.; Hong, J.; Zhang, Y.; Li, J.; Jing, F.; Chu, W. Preparation of stable and highly active $\mathrm{Ni} / \mathrm{CeO}_{2}$ catalysts by glow discharge plasma technique for glycerol steam reforming. Appl. Catal. B Environ. 2019, 249, 257-265. [CrossRef]

91. Silva, J.M.; Ribeiro, L.S.; Órfão, J.; Tosti, S.; Soria, M.; Madeira, L.M. From sorption-enhanced reactor to sorption-enhanced membrane reactor: A step towards $\mathrm{H}_{2}$ production optimization through glycerol steam reforming. Chem. Eng. J. 2019, 368, 795-811. [CrossRef]

92. Zhao, H.; Xu, C.; Wang, T. Production of methane from biomass glycerol through coupling of steam reforming and methanation on Ni-Mn/ $/ \mathrm{Al}_{2} \mathrm{O}_{3}$. Sustain. Chem. Pharm. 2019, 13, 100150. [CrossRef]

93. Rennard, D.C.; Kruger, J.S.; Schmidt, L.D. Autothermal Catalytic Partial Oxidation of Glycerol to Syngas and to Non-Equilibrium Products. ChemSusChem 2009, 2, 89-98. [CrossRef]

94. Moreira, R.; Moral, A.; Bimbela, F.; Portugal, A.; Ferreira, A.; Sanchez, J.L.; Gandía, L.M. Syngas production via catalytic oxidative steam reforming of glycerol using a $\mathrm{Co} / \mathrm{Al}$ coprecipitated catalyst and different bed fillers. Fuel Process. Technol. 2019, 189, 120-133. [CrossRef]

95. Dauenhauer, P.; Salge, J.; Schmidt, L. Renewable hydrogen by autothermal steam reforming of volatile carbohydrates. J. Catal. 2006, 244, 238-247. [CrossRef]

96. Wang, W. Thermodynamic analysis of glycerol partial oxidation for hydrogen production. Fuel Process. Technol. 2010, 91, 1401-1408. [CrossRef]

97. Lin, K.-H.; Chang, A.C.-C.; Lin, W.-H.; Chen, S.-H.; Chang, C.-Y.; Chang, H.-F. Autothermal steam reforming of glycerol for hydrogen production over packed-bed and $\mathrm{Pd} / \mathrm{Ag}$ alloy membrane reactors. Int. J. Hydrog. Energy 2013, 38, 12946-12952. [CrossRef]

98. Iriondo, A.; Barrio, V.; Cambra, J.F.; Arias, P.L.; Güemez, M.; Sanchez-Sanchez, M.; Navarro, R.; Fierro, J. Glycerol steam reforming over Ni catalysts supported on ceria and ceria-promoted alumina. Int. J. Hydrog. Energy 2010, 35, 11622-11633. [CrossRef]

99. Iriondo, A.; Barrio, V.; Cambra, J.F.; Arias, P.L.; Güemez, M.; Navarro, R.; Sanchez-Sanchez, M.; Fierro, J. Influence of $\mathrm{La}_{2} \mathrm{O}_{3}$ modified support and $\mathrm{Ni}$ and $\mathrm{Pt}$ active phases on glycerol steam reforming to produce hydrogen. Catal. Commun. 2009, 10, 1275-1278. [CrossRef]

100. Sánchez, E.A.; D'Angelo, M.A.; Comelli, R.A. Hydrogen production from glycerol on Ni/ $\mathrm{Al}_{2} \mathrm{O}_{3}$ catalyst. Int. J. Hydrog. Energy 2010, 35, 5902-5907. [CrossRef]

101. Adhikari, S.; Fernando, S.; Haryanto, A. Production of hydrogen by steam reforming of glycerin over alumina-supported metal catalysts. Catal. Today 2007, 129, 355-364. [CrossRef]

102. Pant, K.K.; Jain, R.; Jain, S. Renewable hydrogen production by steam reforming of glycerol over $\mathrm{Ni} / \mathrm{CeO}_{2}$ catalyst prepared by precipitation deposition method. Korean J. Chem. Eng. 2011, 28, 1859-1866. [CrossRef]

103. Gil Seo, J.; Youn, M.H.; Park, S.; Chung, J.S.; Song, I.K. Hydrogen production by steam reforming of liquefied natural gas (LNG) over $\mathrm{Ni} / \mathrm{Al}_{2} \mathrm{O}_{3}-\mathrm{ZrO}_{2}$ xerogel catalysts: Effect of calcination temperature of $\mathrm{Al}_{2} \mathrm{O}_{3}-\mathrm{ZrO}_{2}$ xerogel supports. Int. J. Hydrog. Energy 2009, 34, 3755-3763.

104. Sánchez, E.A.; Comelli, R.A. Hydrogen by glycerol steam reforming on a nickel-alumina catalyst: Deactivation processes and regeneration. Int. J. Hydrog. Energy 2012, 37, 14740-14746. [CrossRef]

105. Ni, M.; Leung, D.Y.; Leung, M.K. A review on reforming bio-ethanol for hydrogen production. Int. J. Hydrog. Energy 2007, 32, 3238-3247. [CrossRef]

106. Cheng, C.K.; Foo, S.Y.; Adesina, A.A. H2-rich synthesis gas production over $\mathrm{Co} / \mathrm{Al}_{2} \mathrm{O}_{3}$ catalyst via glycerol steam reforming. Catal. Commun. 2010, 12, 292-298. [CrossRef]

107. Soares, R.R.; Simonetti, D.A.; Dumesic, J.A. Glycerol as a Source for Fuels and Chemicals by Low-Temperature Catalytic Processing. Angew. Chem. Int. Ed. 2006, 45, 3982-3985. [CrossRef]

108. Simonetti, D.; Kunkes, E.; Dumesic, J. Gas-phase conversion of glycerol to synthesis gas over carbon-supported platinum and platinum-rhenium catalysts. J. Catal. 2007, 247, 298-306. [CrossRef]

109. Liu, S.; Yan, Z.; Zhang, Y.; Wang, R.; Luo, S.-Z.; Jing, F.; Chu, W. Carbon Nanotubes Supported Nickel as the Highly Efficient Catalyst for Hydrogen Production through Glycerol Steam Reforming. ACS Sustain. Chem. Eng. 2018, 6, 14403-14413. [CrossRef] 
110. Adhikari, S.; Fernando, S.; Gwaltney, S.; Filipto, S.; Markbricka, R.; Steele, P.; Haryanto, A. A thermodynamic analysis of hydrogen production by steam reforming of glycerol. Int. J. Hydrog. Energy 2007, 32, 2875-2880. [CrossRef]

111. Güell, B.M.; Babich, I.; Nichols, K.; Gardeniers, J.; Lefferts, L.; Seshan, K. Design of a stable steam reforming catalyst-A promising route to sustainable hydrogen from biomass oxygenates. Appl. Catal. B Environ. 2009, 90, 38-44. [CrossRef]

112. Nichele, V.; Signoretto, M.; Menegazzo, F.; Gallo, A.; Santo, V.D.; Cruciani, G.; Cerrato, G. Glycerol steam reforming for hydrogen production: Design of Ni supported catalysts. Appl. Catal. B Environ. 2012, 111, 225-232. [CrossRef]

113. Iriondo, A.; Cambra, J.F.; Güemez, M.; Barrio, V.; Requies, J.; Sanchez-Sanchez, M.; Navarro, R. Effect of $\mathrm{ZrO} 2$ addition on $\mathrm{Ni} / \mathrm{Al}_{2} \mathrm{O}_{3}$ catalyst to produce $\mathrm{H}_{2}$ from glycerol. Int. J. Hydrog. Energy 2012, 37, 7084-7093. [CrossRef]

114. Shejale, A.D.; Yadav, G.D. Ni-Cu and Ni-Co Supported on La-Mg Based Metal Oxides Prepared by Coprecipitation and Impregnation for Superior Hydrogen Production via Steam Reforming of Glycerol. Ind. Eng. Chem. Res. 2018, 57, 4785-4797. [CrossRef]

115. Adhikari, S.; Fernando, S.D.; To, S.D.F.; Bricka, R.M.; Steele, P.H.; Haryanto, A. Conversion of Glycerol to Hydrogen via a Steam Reforming Process over Nickel Catalysts. Energy Fuels 2008, 22, 1220-1226. [CrossRef]

116. Nakagawa, K.; Hideshima, S.; Akamatsu, N.; Matsui, N.-O.; Ikenaga, N.-O.; Suzuki, T. $\mathrm{CO}_{2}$ Reforming of Methane over Ru-Loaded Lanthanoid Oxide Catalysts. In ACS Symposium Series; American Chemical Society (ACS): Washington, DC, USA, 2002; Volume 809, pp. 205-223.

117. Dahdah, E.; Aouad, S.; Gennequin, C.; Estephane, J.; Nsouli, B.; Aboukaïs, A.; Abi-Aad, E. Glycerol steam reforming over $\mathrm{Ru}-\mathrm{Mg}-\mathrm{Al}$ hydrotalcite-derived mixed oxides: Role of the preparation method in catalytic activity. Int. J. Hydrog. Energy 2018, 43, 19864-19872. [CrossRef]

118. Dieuzeide, M.; Laborde, M.; Amadeo, N.; Cannilla, C.; Bonura, G.; Frusteri, F. Hydrogen production by glycerol steam reforming: How $\mathrm{Mg}$ doping affects the catalytic behaviour of $\mathrm{Ni} / \mathrm{Al}_{2} \mathrm{O}_{3}$ catalysts. Int. J. Hydrog. Energy 2016, 41, 157-166. [CrossRef]

119. EN ISO 14040 Environmental Management, Life Cycle Assessment, Principles and Framework; International Organization for Standardization: Geneva, Switzerland, 2006.

120. EN ISO 14044 Environmental Management, Life Cycle Assessment, Requirements and Guidelines; International Organization for Standardization: Geneva, Switzerland, 2006.

121. Tripodi, A.; Bahadori, E.; Cespi, D.; Passarini, F.; Cavani, F.; Tabanelli, T.; Rossetti, I. Acetonitrile from Bioethanol Ammoxidation: Process Design from the Grass-Roots and Life Cycle Analysis. ACS Sustain. Chem. Eng. 2018, 6, 5441-5451. [CrossRef]

122. Neri, E.; Cespi, D.; Setti, L.; Gombi, E.; Bernardi, E.; Vassura, I.; Passarini, F. Biomass Residues to Renewable Energy: A Life Cycle Perspective Applied at a Local Scale. Energies 2016, 9, 922. [CrossRef]

123. Neri, E.; Passarini, F.; Cespi, D.; Zoffoli, F.; Vassura, I. Sustainability of a bio-waste treatment plant: Impact evolution resulting from technological improvements. J. Clean. Prod. 2018, 171, 1006-1019. [CrossRef]

124. Susmozas, A.; Iribarren, D.; Dufour, J. Assessing the Life-Cycle Performance of Hydrogen Production via Biofuel Reforming in Europe. Resources 2015, 4, 398-411. [CrossRef]

125. Unlu, D.; Hilmioglu, N.D. Application of aspen plus to renewable hydrogen production from glycerol by steam reforming. Int. J. Hydrog. Energy 2019. [CrossRef]

126. Cormos, A.-M.; Cormos, C.-C. Techno-economic and environmental performances of glycerol reforming for hydrogen and power production with low carbon dioxide emissions. Int. J. Hydrog. Energy 2017, 42, 7798-7810. [CrossRef]

127. Patcharavorachot, Y.; Chatrattanawet, N.; Arpornwichanop, A.; Assabumrungrat, S. Optimization of hydrogen production from three reforming approaches of glycerol via using supercritical water with in situ $\mathrm{CO}_{2}$ separation. Int. J. Hydrog. Energy 2019, 44, 2128-2140. [CrossRef]

128. Aspen Technology, Inc. 20 Crosby Drive Bedford, Massachusetts 01730 USA. Available online: https: //www.aspentech.com/en/products/engineering/aspen-plus (accessed on 26 August 2019).

129. Turton, R.; Bailie, R.C.; Whiting, W.B.; Shaeiwitz, J.A. Analysis, Synthesis, and Design of Chemical Processes, 2nd ed.; Prentice Hall: Upper Saddle River, NJ, USA, 2003.

130. Galera, S.; Ortiz, F.G.; Ortiz, F.J.G. Life cycle assessment of hydrogen and power production by supercritical water reforming of glycerol. Energy Convers. Manag. 2015, 96, 637-645. [CrossRef] 
131. Galera, S.; Ortiz, F.G.; Ortiz, F.J.G. Techno-economic assessment of hydrogen and power production from supercritical water reforming of glycerol. Fuel 2015, 144, 307-316. [CrossRef]

132. Khila, Z.; Baccar, I.; Jemel, I.; Hajjaji, N. Thermo-environmental life cycle assessment of hydrogen production by autothermal reforming of bioethanol. Energy Sustain. Dev. 2017, 37, 66-78. [CrossRef]

(C) 2019 by the authors. Licensee MDPI, Basel, Switzerland. This article is an open access article distributed under the terms and conditions of the Creative Commons Attribution (CC BY) license (http://creativecommons.org/licenses/by/4.0/). 